\title{
Mechanistically elucidating the in vitro safety and efficacy of a novel doxorubicin derivative
}

\author{
Samaa Alrushaid ${ }^{1}$, Yunqi Zhao ${ }^{2}$, Casey L. Sayre ${ }^{1,3}$, Zaid H. Maayah ${ }^{4}$, M. Laird Forrest ${ }^{5}$, \\ Sanjeewa N. Senadheera ${ }^{5}$, Kevin Chaboyer ${ }^{1,6}$, Hope D. Anderson ${ }^{1,6}$, Ayman O. S. El-Kadi $^{4}$, \\ and Neal M. Davies ${ }^{4}$ \\ ${ }^{1}$ College of Pharmacy, Rady Faculty of Health Sciences, University of Manitoba, Winnipeg, MB \\ R3E 0T5, Canada \\ ${ }^{2}$ School of Pharmaceutical Sciences and Yunnan Provincial Key Laboratory of Pharmacology for \\ Natural Products, Kunming Medical University, Kunming 650500, Yunnan, People's Republic of \\ China \\ ${ }^{3}$ College of Pharmacy, Roseman University of Health Sciences, South Jordan, UT 84096, USA \\ ${ }^{4}$ Faculty of Pharmacy and Pharmaceutical Sciences, University of Alberta, Edmonton, AB T6G \\ 2R3, Canada \\ ${ }^{5}$ Department of Pharmaceutical Chemistry, School of Pharmacy, University of Kansas, Lawrence, \\ KS 66047, USA \\ ${ }^{6}$ Canadian Centre for Agri-Food Research in Health and Medicine, St. Boniface Hospital \\ Research Centre, Winnipeg, MB R2H 2A6, Canada
}

\section{Abstract}

Doxorubicin is an effective anticancer drug; however, it is cardiotoxic and has poor oral bioavazilability. Quercetin is a plant-based flavonoid with inhibitory effects on P-glycoprotein (Pgp) and CYP3A4 and also antioxidant properties. To mitigate these therapeutic barriers, DoxQ, a novel derivative of doxorubicin, was synthesized by conjugating quercetin to doxorubicin. The purpose of this study is to mechanistically elucidate the in vitro safety and efficacy of DoxQ. Drug release in vitro and cellular uptake by multidrug-resistant canine kidney (MDCK-MDR) cells were quantified by HPLC. Antioxidant activity, CYP3A4 inhibition, and P-gp inhibitory effects were examined using commercial assay kits. Drug potency was assessed utilizing triple-negative murine breast cancer cells, and cardiotoxicity was assessed utilizing adult rat and human cardiomyocytes (RL-14). Levels of reactive oxygen species and gene expression of cardiotoxicity markers, oxidative stress markers, and CYP1B1 were determined in RL-14. DoxQ was less cytotoxic to both rat and human cardiomyocytes and retained anticancer activity. Levels of ROS and markers

Correspondence to: Neal M. Davies.

Dr. Yunqi Zhao was instrumental in developing the chemical synthesis of the drug (DoxQ), and this contribution is equal to the first author Samaa Alrushaid.

Compliance with ethical standards Adult rat ventricular cardiomyocytes isolation procedure was approved by the University of Manitoba Office of Research Ethics and Compliance and Animal Care Committee, and were conducted in accordance with guidelines by the Canadian Council for Animal Care.

Conflict of interest The authors declare that they have no conflict of interest. 
of oxidative stress demonstrate lower oxidative damage induced by DoxQ compared to doxorubicin. DoxQ also inhibited the expression and catalytic activity of CYP1B1. Additionally, DoxQ inhibited CYP3A4 and demonstrated higher cellular uptake by MDCK-MDR cells than doxorubicin. DoxQ provides a novel therapeutic approach to mitigate the cardiotoxicity and poor oral bioavailability of doxorubicin. The cardioprotective mechanism of DoxQ likely involves scavenging ROS and CYP1B1 inhibition, while the mechanism of improving the poor oral bioavailability of doxorubicin is likely related to inhibiting CYP3A4 and P-gp.

\section{Keywords}

Doxorubicin; Quercetin; Cardiotoxicity; Bioavailability

\section{Introduction}

Doxorubicin, also called adriamycin, is an anticancer drug used to treat lymphomas and breast and ovarian cancers [1]. The anticancer activity of doxorubicin is due to its intercalation between the two strands of DNA, inhibiting the activity of topoisomerase and DNA synthesis [2,3]. Despite the clinical effectiveness of doxorubicin, its use is limited by off-target adverse effects particularly dose-related cardiotoxicity, which can be life threatening [4]. Additionally, doxorubicin is a substrate of the P-glycoprotein (P-gp) efflux pump [5] and cytochrome P450 metabolic enzymes [6], both of which contribute to its poor oral absorption and low oral bioavailability. For this reason, doxorubicin is only available as a parenteral treatment, which is administered intravenously as a hydrochloride salt formulation.

Over the years, several attempts were undertaken to overcome these limitations including drug delivery systems such as micelles [7], synthetic polymer conjugates [8], and antibodytargeted carriers [9] with varied success. The currently available formulation of doxorubicin (Doxil ${ }^{\mathrm{TM}}$ ) is a pegylated liposomal formulation [10] that is administered intravenously and retains the risk of cardiotoxicity.

The potential therapeutic utility of polyphenols, including flavonoids, is being studied extensively [11]. One flavonoid found in plant-based food with potential health benefits is quercetin. Quercetin has been reported to have a role in prevention of diseases such as liver disease [12], pulmonary hypertension [13], and other cardiovascular diseases [14].

Furthermore, quercetin exhibits anti-inflammatory [15], anticancer [16], and antioxidant [17, 18] effects.

Preliminary studies suggest that combining quercetin with doxorubicin may have beneficial effects. Quercetin enhanced the antitumor effect of doxorubicin in HT29 colorectal cancer cell line [19], MCF-7 breast cancer cell line [20], liver cancer cells [21], and K562 human leukemia cell line [22]. Quercetin also showed cardioprotection against cardiotoxicity induced by doxorubicin [23, 24]. Additionally, quercetin could potentially minimize doxorubicin's loss during first-pass metabolism and P-gp efflux by inhibiting CYP3A4 and P-gp and thus enhance its oral bioavailability [25]. Furthermore, quercetin has a natural tendency to be transported to the lymphatics after intraduodenal administration in rat studies 
as its concentrations in the lymph were higher than those in plasma [26]. This observation suggests that quercetin may be preferentially absorbed from the intestine into the lymphatics over the hepatic portal vein, resulting in lower first-pass effect and improved bioavailability. As bioavailability $(F)=1$ - extraction ratio $(E)$, utilizing quercetin as a novel lymphatically targeted carrier for doxorubicin could increase its systemic delivery $(F)$ by increasing its localization and delivery in the lymphatics through a reduction in its first-pass liver metabolism and extraction $(E)$ Here, quercetin was conjugated to doxorubicin via a glycine linker to give DoxQ as a novel derivative and delivery system of doxorubicin. The doxorubicin-quercetin conjugate (DoxQ) may provide a natural lymphatically targeted delivery approach to improve lymphatic metastasis and may also serve as a novel therapeutic delivery approach to improve the safety and tolerability of doxorubicin in patients both parenterally and orally.

In this study, the in vitro safety and efficacy of DoxQ are mechanistically characterized. The efficacy, metabolism, and safety of DoxQ in comparison to doxorubicin are examined for the first time with a potential to enhance the bioavailability, safety, and efficacy of the parent compound utilizing several in vitro assays. Additionally, the effects of DoxQ on adult rat cardiomyocytes and human cardiomyocytes were tested in comparison to doxorubicin to assess its cardiotoxicity and suggest possible mechanisms involved in cardioprotection or cardiotoxicity. The effects of the novel derivative were also examined in murine breast cancer cells to assess anticancer activity.

\section{Materials and methods}

\section{Materials}

Doxorubicin and quercetin were obtained from Sigma-Aldrich (Oakville, ON). Chemical solvents were from Fisher (Ottawa, ON). H-Gly-OtBu-HCl was from Bachem Americas, Inc. (Torrance, CA). Bis(4-nitrophenyl) carbamate was from Alfa Aesar (Tewksbury, MA).

Cayman antioxidant assay kit catalogue\# 709001 was purchased from Cayman Chemical (Ann Arbor, MI), cytochrome P450 kit catalogue\# P2857 was from Life Technologies (Burlington, ON), and P-glycoprotein assay kit catalogue\# V3601 was from Promega (Madison, WI). High-Capacity cDNA Reverse Transcription Kit for 200 or 1000 reactions was obtained from Applied Biosystems (AB).

\section{Chemical synthesis}

The chemical synthesis of the doxorubicin-quercetin conjugate (DoxQ) is shown in Fig. 1. All glassware was oven-dried at $140{ }^{\circ} \mathrm{C}$ prior to use. Dry organic solvents (tetrahydrofuran (THF) and dimethylformamide (DMF)) were used. Reactions were performed at ambient temperature under dry argon.

Compound 1 (quercetin-Gly-tBu)—Quercetin-Gly-tBu was synthesized according to Kim et al. [27], with some modifications. In a 100-ml round-bottom flask (RBF), H-GlyOtBu-HCl (1 g, $6 \mathrm{mmol})$ and bis(4-nitrophenyl) carbonate $(2 \mathrm{~g}, 6.6 \mathrm{mmol})$ were dissolved in $30 \mathrm{ml}$ of dry THF and $15 \mathrm{ml}$ of DMF with stirring. Two milliliters of diisopropylethylamine (DIPEA) was then added to the RBF to initiate the reaction. The reaction was maintained at 
ambient temperature for $24 \mathrm{~h}$. The following day, quercetin $(1.82 \mathrm{~g}, 1.82 \mathrm{mmol})$ was added gradually over $10 \mathrm{~min}$ with stirring. The reaction was maintained for an additional $24 \mathrm{~h}$. The product was transferred to a clean 250-ml RBF and concentrated under reduced pressure. The crude product was further dried overnight under high vacuum. The dried yellowish crude product was purified over the silica gel using a dichloromethane (DCM)/acetone solvent system (gradient solvent system: initially 10:90, then 15:85, and finally 20:80). The fractions were analyzed by TLC (1:10, acetone/DCM). The fractions of interest were combined and concentrated under reduced pressure to afford compound 1 as yellow solid (2 g). ${ }^{1} \mathrm{H}-\mathrm{NMR}$ (acetone- $d_{6}, 400 \mathrm{MHz}$ ): $\delta=12.06(\mathrm{~s}, 1 \mathrm{H}), 9.23(\mathrm{bs}, 1 \mathrm{H}), 7.99(\mathrm{~d}, J=2.2 \mathrm{~Hz}$, $1 \mathrm{H}), 7.96(\mathrm{dd}, J=8.6,2.1 \mathrm{~Hz}, 1 \mathrm{H}), 7.06(\mathrm{~d}, J=8.7 \mathrm{~Hz}, 1 \mathrm{H}), 6.99(\mathrm{t}, J=6.6 \mathrm{~Hz}, 1 \mathrm{H}), 6.46(\mathrm{t}$, $J=2.1 \mathrm{~Hz}, 1 \mathrm{H}), 6.21(\mathrm{t}, J=2.1 \mathrm{~Hz}, 1 \mathrm{H}), 3.86(\mathrm{~d}, J=6.0 \mathrm{~Hz}, 2 \mathrm{H}), 1.43(\mathrm{~s}, 9 \mathrm{H}) ; \mathrm{ESI}(\mathrm{m} / \mathrm{z})$; calculated for $\mathrm{C}_{22} \mathrm{H}_{20} \mathrm{NO}_{10}(\mathrm{M}-\mathrm{H})^{-}: 458.1087$; found: 458.0047 .

Compound 2 (quercetin-Gly-COOH)—Compound $1(2 \mathrm{~g})$ was dissolved in $10 \mathrm{ml}$ of DCM and cooled on ice, and then $40 \mathrm{ml}$ of trifluoroacetic acid (TFA) was added gradually with stirring. An additional $10 \mathrm{ml}$ of DCM was added to rinse the walls of the RBF, and the reaction mixture was stirred for $4 \mathrm{~h}$. The resulting yellow precipitate was filtered under vacuum using a ceramic Buchner funnel fitted with a filter paper. The precipitate was washed with DCM and ice-cold acetone and then oven-dried to afford compound 2 as a yellow solid ( 1 g), which was used for the next step without further purification. ${ }^{1} \mathrm{H}-\mathrm{NMR}$ (DMSO- $\left.d_{6}, 400 \mathrm{MHz}\right): \delta=12.69(\mathrm{bs}, 1 \mathrm{H}), 12.44(\mathrm{~s}, 1 \mathrm{H}), 10.81(\mathrm{bs}, 1 \mathrm{H}), 10.38(\mathrm{bs}, 1 \mathrm{H})$, $9.56(\mathrm{~s}, 1 \mathrm{H}), 8.02(\mathrm{t}, J=6.8 \mathrm{~Hz}, 1 \mathrm{H}), 7.91(\mathrm{dd}, J=8.6,2.3 \mathrm{~Hz}, 1 \mathrm{H}), 7.88(\mathrm{~d}, J=2.2 \mathrm{~Hz}, 1 \mathrm{H})$, $7.06(\mathrm{~d}, J=8.6 \mathrm{~Hz}, 1 \mathrm{H}), 6.47(\mathrm{~d}, J=2.0 \mathrm{~Hz}, 1 \mathrm{H}), 6.21(\mathrm{~d}, J=2.0 \mathrm{~Hz}, 1 \mathrm{H}), 3.77$ (d, $J=6.1$ $\mathrm{Hz}, 2 \mathrm{H})$; $\mathrm{ESI}(\mathrm{m} / \mathrm{z})$; calculated for $\mathrm{C}_{18} \mathrm{H}_{12} \mathrm{NO}_{10}(\mathrm{M}-\mathrm{H})^{-}$: 402.0461 ; found: 402.0419.

Compound 3 (quercetin-Gly-Dox)—Doxorubicin $\mathrm{HCl}$ (500 mg, $0.86 \mathrm{~mol}$ ), compound 2 (900 mg, $2.15 \mathrm{~mol}$ ), and 1-[bis(dimethylamino)methylene]-1H-1,2,3-triazolo[4,5b]pyridinium 3-oxid hexafluorophosphate (HATU) $(655 \mathrm{mg}, 1.72 \mathrm{~mol}$ ) were dissolved in $100 \mathrm{ml}$ of dry DMF with stirring. DIPEA $(1.3 \mathrm{ml}, 6.9 \mathrm{mmol})$ was added last. The reaction was maintained at ambient temperature with stirring over $48 \mathrm{~h}$ in the dark.

The reaction mixture was concentrated under reduced pressure in the dark. The crude product was purified by recrystallization using $\mathrm{MeCN}$ and $\mathrm{MeOH}$ as follows: the crude product was dissolved in a minimum amount of $\mathrm{MeCN} / \mathrm{MeOH}(4: 1,10 \mathrm{ml})$ with the help of sonication and heating $\left(\sim 50-60^{\circ} \mathrm{C}\right)$. The resulting solution was allowed to cool down to facilitate the crystallization, and the RBF was stored overnight at $4{ }^{\circ} \mathrm{C}$ in a refrigerator to facilitate crystallization/precipitation of the product. The dark red product with the solution was transferred into a 50-ml centrifugation tube and centrifuged at $4000 \mathrm{~g}$ for $20 \mathrm{~min}$. The supernatant was decanted. The centrifugation was repeated four times with ice-cold $\mathrm{MeCN} /$ $\mathrm{MeOH}(4: 1,5 \mathrm{ml} \times 4)$. The supernatant was carefully pipetted/ decanted. After the final round of centrifugation, a clear solution of supernatant was observed. The resulting dark red solid residue was collected and dried to afford the final compound 3 (DoxQ, $\sim 500 \mathrm{mg} ;{ }^{1} \mathrm{H}$ NMR (DMSO- $\left.d_{6}, 400 \mathrm{MHz}\right): \delta=8.32(\mathrm{~s}, 1 \mathrm{H}), 7.94(\mathrm{t}, J=6.4 \mathrm{~Hz}, 1 \mathrm{H}), 7.90(\mathrm{~d}, J=1.2 \mathrm{~Hz}$, 1H), $7.88(\mathrm{~s}, 1 \mathrm{H}), 7.79(\mathrm{~s}, 1 \mathrm{H}), 7.71(\mathrm{~s}, 1 \mathrm{H}), 7.15(\mathrm{~d}, J=8.4 \mathrm{~Hz}, 1 \mathrm{H}), 7.06(\mathrm{~d}, J=8.4 \mathrm{~Hz}$, 1H), $6.46(\mathrm{~s}, 1 \mathrm{H}), 6.19(\mathrm{~s}, 1 \mathrm{H}), 5.50(\mathrm{~s}, 1 \mathrm{H}), 5.23(\mathrm{~s}, 1 \mathrm{H}), 4.97(\mathrm{~s}, 1 \mathrm{H}), 4.87(\mathrm{~s}, 2 \mathrm{H}), 4.57(\mathrm{~s}$, 
1H), $4.16(\mathrm{~s}, 1 \mathrm{H}), 4.00-3.89(\mathrm{~m}, 3 \mathrm{H}), 3.07$ (s, 3H), $3.00(\mathrm{~s}, 1 \mathrm{H}), 2.92$ (s, 3H), 2.78 (d, $J=9.6$ $\mathrm{Hz}, 1 \mathrm{H}), 2.68(\mathrm{~d}, J=6.4 \mathrm{~Hz}, 1 \mathrm{H}), 2.21-2.11(\mathrm{~m}, 2 \mathrm{H}), 3.32(\mathrm{~s}, 3 \mathrm{H}), 2.99-2.89(\mathrm{~m}, 2 \mathrm{H})$, 2.84-2.56 (m, 1H), 2.37-2.21 (m, 3H), 1.51-1.41 (m, 1H), $1.24(\mathrm{~s}, 1 \mathrm{H}), 1.13(\mathrm{~d}, J=7.6 \mathrm{~Hz}$, $3 \mathrm{H})$; ESI (m/z); calculated for $\mathrm{C}_{45} \mathrm{H}_{40} \mathrm{~N}_{2} \mathrm{O}_{20}(\mathrm{M}+\mathrm{Na})^{+}$calculated value 951.81 ; found: 951.2089.

\section{In vitro drug release and cellular uptake by MDCK-MDR cells}

In vitro drug release studies-DoxQ release was examined in phosphate-buffered saline (PBS) supplemented with $10 \%$ fetal bovine serum (FBS) at $37^{\circ} \mathrm{C}$. Aliquots $(100 \mu \mathrm{l})$ from the sample were collected at predetermined time intervals and analyzed by HPLC coupled with a fluorescent detector (excitation/emission 480/590).

Cell culture and treatments-MDCK-MDR cells were maintained in high-glucose Dulbecco's modified Eagle's medium (DMEM) with $1 \times$ L-glutamine and sodium pyruvate that was supplemented with $10 \%$ FBS, $1 \times$ non-essential amino acid, and $1 \times$ penicillinstreptomycin. The cells were seeded onto poly-L-lysine precoated glass coverslips (BD, Franklin Lakes, NJ) in a 12-well culture plate at a density of 5000 cells/well.

Cell imaging-After $12 \mathrm{~h}$, the cells were treated with $50 \mathrm{nM}$ free doxorubicin, a mixture of doxorubicin and quercetin, or DoxQ alone with $3 \mu \mathrm{g} / \mathrm{ml}$ DAPI at $15 \mathrm{~min}$ prior to cell imaging. After treatment, the cells were washed three times with PBS. Live cells were rapidly imaged on a Nikon Eclipse 80i epifluorescence microscope (Melville, NY) with a 20 $\times 0.75$ NA objective and a Hamamatsu ORCA ER digital camera (Houston, TX). The GFP filter set (Nikon, NY) was used to image the fluorescence signal from doxorubicin. All images were taken with identical instrument settings and scaled equally so that fluorescence intensity could be compared between independent images and quantified accurately.

Quantification of cellular uptake-Cellular uptake and accumulation of doxorubicin in MDCK-MDR cells was quantified using HPLC. Cells were seeded in 12-well plates at a density of 10,000 cells/well. After the cells attached to the surface, $1 \mu \mathrm{M}$ of doxorubicin, a mixture of doxorubicin and quercetin, or DoxQ was added. After $6 \mathrm{~h}$ of treatment, the supernatant was collected and analyzed. Fluorescence signals were analyzed by ImageJ. Cellular uptake was by quantified by HPLC.

\section{Effects on murine breast cancer cells}

A triple-negative murine breast cancer cell line was maintained in Dulbecco's modified Eagle's medium supplemented with $10 \%$ fetal bovine serum (HyClone Laboratory, Inc., Logan, UT). Cells were plated in white 96-well flat-bottomed plates at the concentration of 5000 cells/well in $90 \mu \mathrm{l}$ of growth medium. After $12 \mathrm{~h}$, the parent compound doxorubicin, quercetin, and a mixture of doxorubicin and quercetin solution were added at different concentrations. Hanks' solution and $10 \%$ trichloroacetic acid (TCA) were used as negative and positive control, respectively. The medium was refreshed $8 \mathrm{~h}$ after treatment. At $72 \mathrm{~h}$ post-treatment, resazurin blue $(5 \mu \mathrm{M})$ was added and the resorufin product was measured with a fluorophotometer using an excitation wavelength of $550 \mathrm{~nm}$ and an emission wavelength of $590 \mathrm{~nm}$. 


\section{Effects on antioxidant activity}

The antioxidant activity of DoxQ, doxorubicin, quercetin, or a mixture of doxorubicin and quercetin was examined using the antioxidant kit from Cayman Chemical. The assay is based on the ability of the antioxidant in the sample to inhibit the oxidation of ABTS® $\left(2,2^{\prime}\right.$-azino-di-[3-ethylbenzthiazoline sulfonate]) to ABTS ${ }^{++}$by metmyoglobin. The amount of ABTS produced is measured by absorbance at $750 \mathrm{~nm}$. Antioxidants will suppress absorbance at $750 \mathrm{~nm}$, and the suppression is proportional to the concentration. The antioxidant capacity is compared to a water-soluble tocopherol analog called Trolox. The result of the assay was expressed as molar Trolox equivalents. More information about the assay can be found in the technical bulletin of the assay kit.

\section{Effects on CYP3A4 activity}

The inhibitory effects of CYP3A4 by DoxQ, doxorubicin, quercetin, or a mixture of doxorubicin and quercetin were examined using CYP Vivid kits from Life Technologies following the manufacturer's instructions. The inhibitory effects of the investigational compounds were compared to ketoconazole as a positive inhibitor of CYP3A4, and the result was expressed as percentage of inhibition. More information about the assay can be found in the technical bulletin of the assay kit.

\section{Effects on P-glycoprotein activity}

The Pgp-Glo kit from Promega was utilized to determine if DoxQ exhibits inhibitory effects on P-gp or not. The assay detects the effects of compounds on recombinant human Pgp in a cell membrane fraction by measuring ATPase activity. More information about the assay can be found in the technical bulletin of the assay kit.

\section{Effects on adult rat cardiomyocytes}

Care of the animals was in full compliance with the Canadian Council on Animal Care, and animal ethics approval was granted by the University of Manitoba Animal Care Committee. Ventricular cardiomyocytes were isolated from adult rats and maintained. The effect of the novel derivative on cell viability was examined in comparison to doxorubicin by trypan blue assay.

Cell isolation-Adult cardiac myocytes were isolated from 6- to 7-week-old rats transferred to 24-well plates containing $500 \mu \mathrm{l}$ of media. The cells were incubated for $2 \mathrm{~h}$ in media.

Cell treatments-The cells were exposed to 1,5 , or $10 \mu \mathrm{M}$ treatments of doxorubicin, DoxQ, or control, 3 \% PEG in DMSO. Stock solutions of the appropriate concentration were directly added to the wells with a micropipette. Treatments were preformed in duplicate with each experiment. Three sets of experimental replicates were preformed. All treatments proceeded under sterile conditions in a biosafety cabinet. Following the treatments, the cells were then incubated at $37^{\circ} \mathrm{C}$ for $18 \mathrm{~h}$.

Cell staining and microscopy-After $18 \mathrm{~h}$ of incubation, $250 \mu \mathrm{l}$ of media was removed from each well and replaced with $250 \mu \mathrm{l}$ of trypan blue dye, which selectively dyes dead 
cells. The wells were then visualized under a bright-field microscope, and six sets of pictures were taken at random for each treatment.

Cell counting-Live and dead cells were manually counted. Dead cells were identified to be of a rounded morphology and visibly darker due to the staining with trypan blue. The ratio of dead to total cell count was then calculated.

\section{Effects on human cardiomyocytes (RL-14)}

Cell culture and treatments-Human cardiomyocytes (RL-14, American Type Cell Culture Patent Deposit Designation PTA-1499, Manassas, VA) were grown in DMEM/F-12 with phenol red supplemented with $12.5 \%$ fetal bovine serum, $20 \mu \mathrm{M} \mathrm{L-glutamate}, 100 \mathrm{IU}$ penicillin $\mathrm{G}$, and $100 \mu \mathrm{g} / \mathrm{ml}$ streptomycin. The cells were grown in $75-\mathrm{cm}^{2}$ tissue culture flasks at $37{ }^{\circ} \mathrm{C}$ in a humidified incubator with $5 \% \mathrm{CO}_{2}$.

The cells were seeded in 12-well culture plates with DMEM/F-12 and then washed with PBS. The cells were then replenished with serum-free media and treated with the compounds of interest for $24 \mathrm{~h}$.

Effect of doxorubicin and DoxQ on cell viability (MTT assay)-The effects of DoxQ on the RL-14 viability were determined utilizing MTT assay. The assay measures the capacity of cells to convert MTT to colored formazan crystals as described previously [28, 29].

Determination of reactive oxygen species levels by DCF assay-RL-14 cells grown to $90 \%$ confluence in 96-well cell culture plates were treated for $24 \mathrm{~h}$ with the tested compounds. Thereafter, the cells were washed with PBS before incubation for $30 \mathrm{~min}$ in fresh media containing $10 \mu \mathrm{M}$ dichlorofluorescein (DCF). Fluorescence measurements at excitation/emission (545/575 nm) of the wells were recorded using the BioTek Synergy H1 Hybrid Multi-Mode Microplate Reader (BioTek Instruments, Winooski, VT, USA).

RNA extraction and cDNA synthesis-Total RNA from the treated cells was isolated using TRIzol reagent (Invitrogen ${ }^{\circledR}$ ) according to the manufacturer's instructions and quantified by measuring the absorbance at $260 \mathrm{~nm}$. RNA purity was determined by measuring the 260:280 ratio (>1.8). Thereafter, first-strand complementary DNA (cDNA) synthesis was performed using the High-Capacity cDNA Reverse Transcription Kit (Applied Biosystems), according to the manufacturer's instructions as described previously [30]. Briefly, $1.5 \mu \mathrm{g}$ of total RNA from each sample was added to a mixture of $2.0 \mu \mathrm{l}$ of $10 \times$ reverse transcriptase buffer, $0.8 \mu \mathrm{l}$ of $25 \times \mathrm{dNTP} \operatorname{mix}(100 \mathrm{mM}), 2.0 \mu \mathrm{l}$ of $10 \times$ reverse transcriptase random primers, $1.0 \mu \mathrm{l}$ of MultiScribe reverse transcriptase, and $4.2 \mu \mathrm{l}$ of nuclease-free water. The final reaction mixture was kept at $25^{\circ} \mathrm{C}$ for $10 \mathrm{~min}$, heated to $37^{\circ} \mathrm{C}$ for $120 \mathrm{~min}$, heated to $85^{\circ} \mathrm{C}$ for $5 \mathrm{~min}$, and finally cooled to $4{ }^{\circ} \mathrm{C}$.

Quantification of mRNA expression by quantitative real-time PCR-Quantitative analysis of specific mRNA expression was performed by real-time polymerase chain reaction (PCR) by subjecting the resulting $1.5 \mu \mathrm{g}$ cDNA to PCR amplification using 96-well optical reaction plates in the ABI PRISM 7500 System (Applied Biosystems) [31]. The $25 \mu \mathrm{l}$ 
reaction mixture contained $0.1 \mu \mathrm{l}$ of $10 \mu \mathrm{M}$ forward primer and $0.1 \mu \mathrm{l}$ of $10(\mu \mathrm{M}$ reverse primer ( $40 \mathrm{nM}$ final concentration of each primer), $12.5 \mu \mathrm{l}$ of SYBR Green Universal Master Mix, $11.05 \mu \mathrm{l}$ of nuclease-free water, and $1.25 \mu \mathrm{l}$ of cDNA sample. Human and rat primer sequences for BNP, a-myocin heavy chain ( $\alpha$-MHC), $\beta$-myocin heavy chain ( $\beta$-MHC), GST-A1, HO-1, CYP1B1, and $\beta$-actin are illustrated in Table 1. These primers were purchased from Integrated DNA Technologies (IDT, Coralville, IA). The ratio of $\beta$-MHC to a-MHC expression was quantitated by assessing relative cDNA levels of the genes compared with $\beta$-actin expression from the same sample. The real-time PCR data was analyzed using the relative gene expression (i.e., $\Delta \Delta \mathrm{CT}$ ) method, as described and explained previously [32]. Briefly, the fold change in the level of target genes between the treated and untreated cells, corrected for the level of $\beta$-actin, was determined using the following equation: fold change $=2^{-\Delta(\Delta \mathrm{Ct})}$, where $\Delta \mathrm{Ct}=\mathrm{Ct}_{(\text {target })}-\mathrm{Ct}_{(\beta \text {-actin })}$ and $\Delta(\Delta \mathrm{Ct})=\Delta \mathrm{Ct}\left(_{\text {treated }}\right)$ $-\Delta \mathrm{Ct}($ untreated).

Determination of CYP1B1 enzymatic activity-CYP1B1-dependent methoxyresorufin O-deethylase (MROD) and ethoxyresorufin O-deethylase (EROD) activity was performed on intact living RL-14 cells [33, 34]. After incubation of the cells with the test compounds, $100 \mu \mathrm{l}$ of $2 \mu \mathrm{M}$ MROD or EROD in assay buffer $(0.05 \mathrm{M}$ Tris, $0.1 \mathrm{M} \mathrm{NaCl}$, $\mathrm{pH}$ 7.8) was then added to each well. Immediately, an initial fluorescence measurement $(t=$ 0 ) at excitation/emission $(545 / 575 \mathrm{~nm})$ was recorded followed by an additional set of fluorescence measurements of the samples that were recorded every $5 \mathrm{~min}$ for $40 \mathrm{~min}$ using the BioTek Synergy H1 Hybrid Multi-Mode Microplate Reader (BioTek Instruments, Winooski, VT, USA).

\section{Statistical analysis}

Compiled data were presented as mean and standard error of the mean (mean $\pm \mathrm{SEM}$ ). Where possible, data were statistically analyzed by SigmaPlot ${ }^{\circledR}$ for Windows (Systat Software, Inc, CA) or GraphPrism, with a $P$ value $<0.05$ being considered statistically significant. One-way analysis of variance (ANOVA) followed by the Tukey-Kramer multiple comparison test was employed to assess which treatment group(s) showed a significant difference from the control group.

\section{Results}

\section{In vitro drug release and cellular uptake by MDCK-MDR cells}

In vitro DoxQ release-To assess the post-administration fate of DoxQ, the in vitro release of the conjugate was examined. The in vitro drug release scheme is shown in Fig. 2. The release of doxorubicin was due to the enzyme digestion of the amide bond. The release of doxorubicin from the conjugate showed a first-order kinetic profile, and the release halflife $\left(t_{1 / 2}\right)$ was approximately $60 \mathrm{~h}$ (Fig. 3). Quercetin was released from the conjugate by hydrolyzing the carbamate bond. The release of quercetin exhibited second-order kinetics in aqueous medium with $t_{1 / 2}$ of approximately $100 \mathrm{~h}$.

Drug uptake by MDCK-MDR cells-To assess the efficacy of DoxQ, the uptake of the novel conjugate was examined in MDCK-MDR cells, a P-gp-positive cell line. Confocal 
microscopy was used to examine if the novel derivative can improve doxorubicin's uptake by P-gp-positive cells. The fluorescence signal detected in the cells treated with a mixture of doxorubicin and quercetin or DoxQ was higher than that in the group treated with free doxorubicin (Fig. 4). The images were analyzed by Image J (Fig. 5a). After 5-min treatment, there was no significant improvement of drug uptake by the cells treated with the doxorubicin plus quercetin mixture compared to that of free doxorubicin. However, the fluorescence signal was significantly enhanced in the cells treated with DoxQ $(P<0.05)$.

Drug uptake by the cells was quantified by HPLC as shown in Fig. 5b. The novel formulation significantly improved drug uptake compared to both free doxorubicin and a mixture of doxorubicin and quercetin. This is consistent with the fluorescence imaging study (Figs. 4 and 5a).

\section{Effect of DoxQ on murine breast cancer cells}

The cytotoxicity of doxorubicin was evaluated in a triple-negative murine breast cancer cell line by resazurin blue assay in comparison to DoxQ or a mixture of doxorubicin and quercetin to assess its anticancer activity. DoxQ was substantially less toxic than doxorubicin or a mixture of doxorubicin and quercetin mixture. $\mathrm{IC}_{50}$ of DoxQ was more than twofold higher than that of doxorubicin alone or a mixture of doxorubicin and quercetin (Fig. 6). The decreased cytotoxicity of DoxQ could be partially due to the very poor water solubility and the relatively slow release of doxorubicin from the conjugate.

\section{Antioxidant activity}

To understand the possible mechanism involved in attenuating doxorubicin-induced cardiotoxicity by DoxQ, the antioxidant capacity of DoxQ was investigated. The antioxidant effect was studied utilizing an assay that compares the antioxidant capacity of the investigational compound to that of a positive control (Trolox). The antioxidant capacity of doxorubicin, DoxQ, quercetin, and a mixture of doxorubicin and quercetin was evaluated at $1,10,50$, and $100 \mathrm{mM}$ and showed a dose-response effect in all study groups (Fig. 7). DoxQ showed a significantly higher antioxidant effect compared to doxorubicin at all concentrations studied. Similarly, the antioxidant capacity of DoxQ at 10 and $50 \mathrm{mM}$ DoxQ was significantly higher than that of a mixture of doxorubicin and quercetin, while at 1 and $10 \mathrm{mM}$ DoxQ, it was significantly higher than that of quercetin alone.

\section{Effect on CYP3A4 inhibition}

To elucidate the possible mechanisms involved in improving the bioavailability of doxorubicin, the effect of DoxQ on CYP3A4 inhibition was investigated. CYP3A4 is the major metabolic enzyme involved in first-pass effect. Inhibitory effects of CYP3A4 by the test compounds were compared to those of ketoconazole at $0.01,0.1,1,10,50$, and $100 \mu \mathrm{M}$, and the result was expressed as percentage of inhibition relative to ketoconazole. The results show that DoxQ inhibited CYP3A4 at all the concentrations tested, with the highest inhibition at $0.01 \mu \mathrm{M}$ (Fig. 8). A mixture of doxorubicin and quercetin did not inhibit CYP3A4 except at $100 \mu \mathrm{M}$, which could be due to instability of quercetin, dimerization, or its precipitation [35]. 


\section{Effect on P-gp ATPase activity}

The effects of DoxQ on P-gp were examined in comparison to doxorubicin, quercetin, or a mixture of doxorubicin and quercetin to elucidate the possible role of P-gp inhibition in improving the bioavailability of doxorubicin. At the concentration range of 1-100 $\mu \mathrm{M}$, there was no statistically different ATPase activity between DoxQ and doxorubicin. At $200 \mu \mathrm{M}, \mathrm{P}-$ gp ATPase activity of DoxQ was lower than that of doxorubicin by 0.6 fold, suggesting slight P-gp inhibition effects. However, a mixture of doxorubicin and quercetin significantly reduced P-gp ATPase activity by $0.8-1.2$ folds at $50-200 \mu \mathrm{M}$ concentration compared to free doxorubicin (Fig. 9). Quercetin alone reduced P-gp ATPase activity at all concentrations, supporting its P-gp inhibitory effects documented in the literature.

\section{Effect of DoxQ on rat cardiomyocyte cell viability}

To assess the safety of DoxQ, the effects of DoxQ on rat cardiomyocytes were examined at 1,5 , and $10 \mu \mathrm{M}$ in comparison to doxorubicin by trypan blue assay. A dose-response effect was observed with both doxorubicin and DoxQ (Fig. 10a). At $10 \mu \mathrm{M}$, doxorubicin treatment resulted in $\sim 22 \%$ cell death, while DoxQ treatment resulted in $\sim 17 \%$ cell death; both were statistically significant from the baseline. Additionally, the lower percentage of cell death in the cells treated with DoxQ at $10 \mu \mathrm{M}$ was statistically significant from the cells treated with doxorubicin alone at the same concentration (Fig. 10b).

\section{Effects on human cardiomyocytes (RL-14 cells)}

Effect of DoxQ on RL-14 cell viability-To further confirm the safety of DoxQ, the effects of DoxQ or doxorubicin on human cardiomyocytes was investigated after treatment at $10 \mu \mathrm{M}$ for $24 \mathrm{~h}$ by MTT assay. The results show that cell viability was higher in the group of cells treated with DoxQ (77\%) than in the group of cells treated with free doxorubicin (52\%), indicating that DoxQ prevented the cytotoxicity mediated by doxorubicin by $\sim 25 \%$ (Fig. 11).

Effect of DoxQ on reactive oxygen species-To elucidate whether DoxQ may protect cardiomyocytes from the damage caused by doxorubicin via generating ROS, the levels of ROS generated after treatment of RL-14 cells with doxorubicin, DoxQ, or quercetin were measured by DCF assay. The level of ROS in the cells treated with DoxQ (556\%) was higher than that in the cells treated with free doxorubicin (322\%) by $234 \%$ (Fig. 12).

Effect of DoxQ on induction of cellular cardiotoxicity markers-To further confirm the protective effects of DoxQ against doxorubicin-induced cardiotoxicity, the expression of three cardiac hypertrophy markers ( $\mathrm{a}-\mathrm{MHC}, \beta-\mathrm{MHC}$, and BNP) was examined in RL-14 cells after treatment at $10 \mu \mathrm{M}$ for $24 \mathrm{~h}$ of test compounds.

DoxQ significantly inhibited the induction of mRNA expression of a-MHC by 1.5 folds, $\beta$ MHC by 2.5 folds, and BNP by 6 folds compared to doxorubicin (Fig. 13). The expression of all three hypertrophic markers in the group of cells treated with quercetin was similar to that of the control untreated cells, supporting the protective role of quercetin in cardiomyocytes. 
Effect of DoxQ on the induction of cellular oxidative stress markers-To further confirm the cardioprotective effects of DoxQ and the role of oxidative stress in promoting cardiotoxicity by doxorubicin, the expression of oxidative stress markers GST-A1 and HO-1 was investigated in RL-14 cells. DoxQ significantly lowered the mRNA expression of GSTA1 by 1.5 folds in comparison to doxorubicin (Fig. 14a). The expression of HO-1 was lower by 1 fold in the cells treated with doxorubicin compared to the cells treated with DoxQ (Fig. 14b).

Effect of DoxQ on gene expression and catalytic activity of CYP1B1-To further elucidate the cardioprotective effects of DoxQ, the capacity of DoxQ to alter the induction of the CYP1B1 gene by doxorubicin as well as its catalytic activity was investigated in RL-14 cells. Figure 14a demonstrates that DoxQ inhibited the mRNA expression of CYP1B1 by more than 4 folds compared to doxorubicin (Fig. 15a). The catalytic activity of CYP1B1 was also significantly inhibited by DoxQ compared to doxorubicin alone (Fig. 15b, c).

\section{Discussion}

Doxorubicin is an effective chemotherapeutic anticancer agent used in a variety of cancers. However, its use is often limited by dose-related cardiotoxicity as the cumulative dose of doxorubicin concentrates in the heart and may progress to severe cardiomyopathy and even death. The cardiotoxicity of doxorubicin is related to the generation of reactive oxygen species such as superoxides and subsequently hydrogen peroxide. In addition, the expression of certain cardiotoxicity markers and metabolic enzymes is altered with doxorubicin therapy and is involved in doxorubicin-induced cardiotoxicity.

The currently available pegylated liposomal formulation of doxorubicin Doxil ${ }^{\mathrm{TM}}$ preferentially concentrates in the skin, resulting in palmar-plantar erythrodysesthesia (PPE) syndrome $[10,36]$. There is another liposomal non-pegylated formulation of doxorubicin called Myocet $^{\mathrm{TM}}$ that significantly reduces hand-foot syndrome. Both liposomal formulations provide sustained release of doxorubicin, thus minimizing the acute cardiotoxicity caused by high maximum plasma concentration (Cmax) to some extent compared to the doxorubicin hydrochloric salt when administered intravenously.

A doxorubicin-hyaluronic acid conjugate (Dox-HA) has previously shown promise in the treatment of breast cancer and metastatic lymph nodes [37]. The Dox-HA was encapsulated in a nanocarrier and administered sub-cutaneously into the mammary tumors of nude mice. The Dox-HA provided localization in the breast tissue and also provided a sustained release of doxorubicin, both contributing to lower systemic toxicities caused by doxorubicin while retaining efficacy.

Consistent with the promising results of a Dox-HA [37], we designed a novel derivative of doxorubicin utilizing a flavonoid that is naturally consumed in fruits and vegetables and reported to have health benefits, P-gp and CYP3A4 inhibitory activities [25], and a preferential tendency to intestinal lymphatic absorption [26, 38, 39]. The novel compound (DoxQ) was chemically synthesized by conjugating doxorubicin to a naturally occurring flavonoid, quercetin, via a peptide linker, "glycine" (Fig. 1), and can be administered orally 
or intravenously. The release of doxorubicin is accomplished by a simple cleavage of the peptide bond of glycine by proteases followed by the cleavage of the carbamate bond to release quercetin (Fig. 2).

The purpose of this study is to elucidate the in vitro efficacy and safety of DoxQ with a potential to mitigate the poor oral bioavailability and dose-related cardiotoxicity of doxorubicin. The possible mechanisms by which DoxQ mitigates these therapeutic limitations are also described. In terms of efficacy, we have shown that both doxorubicin and quercetin are released from the conjugate in vitro. The slow in vitro release of doxorubicin from the conjugate over more than 4 days (Fig. 3) may translate into a lower peak plasma concentration, thus limiting acute cardiotoxicity. Additionally, DoxQ retained its anticancer activity in triple-negative murine breast cancer cells with $\mathrm{IC}_{50}$ in the micromolar range.

The low oral bioavailability of doxorubicin is due to its limited uptake by intestinal cells expressing P-gp as it is a substrate of the P-gp efflux pump and also its extensive first-pass metabolism by CYP3A4 [40-42]. The cellular uptake of DoxQ as well as a mixture of doxorubicin and quercetin by P-gp-positive cells (Figs. 4 and 5) and the inhibitory effects on P-gp ATPase by a mixture of doxorubicin and quercetin (Fig. 9) suggest that the release of quercetin from DoxQ plays a role in minimizing the Pgp efflux effect of doxorubicin and enhances its uptake by P-gp-positive cells. We then investigated the effect of DoxQ on CYP3A4 inhibition, as it is the major metabolic enzyme contributing to first-pass effect and also many compounds that inhibit Pgp are inhibitors of CYP3A4. Figure 8 shows that DoxQ acts as an inhibitor of CYP3A4, which could limit the loss of doxorubicin by first-pass metabolism and potentially improve its bioavailability. The overall improvement in the bioavailability of doxorubicin by DoxQ sheds light on the therapeutic utility of DoxQ as a novel delivery approach for oral administration of doxorubicin and may also lower the required dose of doxorubicin to achieve effective concentrations when administered intravenously.

To assess the safety of DoxQ, the effects of the novel conjugate were initially investigated in isolated adult rat cardiomyocytes. DoxQ showed a lower cytotoxicity profile in rat cardiomyocytes at the concentration range tested in comparison to doxorubicin alone (Fig. 10). The effects of DoxQ were then examined in RL-14 cells, a commercially available cell line isolated from human ventricular tissues, which is commonly used to investigate molecular mechanisms and toxic effects induced by chemotherapeutic agents like doxorubicin [43, 44]. Before conducting experiments in RL-14 cells, $10 \mu \mathrm{M}$ concentration was selected based on the reported therapeutic plasma concentration of doxorubicin in humans $[45,46]$ as well as other in vitro studies that examined the cardiotoxic effects of doxorubicin [47, 48]. Our study shows that DoxQ was less toxic to RL-14 (Fig. 11) as evident by MTT assay and consistent with the observation from the trypan blue assay in rat cardiomyocytes. The expression of cardiac hypertrophy markers a-MHC, $\beta$-MHC, and BNP was examined in RL-14 cells to further confirm the protective effects of DoxQ on cardiomyocytes. Chronic treatment with doxorubicin causes cardiotoxicity that may progress to cardiac myopathy and heart failure via multiple cellular pathways [49]. Maayah et al. reported that treatment of RL-14 cells with doxorubicin caused cardiotoxicity manifested by induction in the expression of $\beta$-MHC/a-MHC genes [50]. Furthermore, 
Chen et al. showed that doxorubicin enhanced the protein expression of BNP and $\beta$-MHC while reducing the expression of $\alpha-\mathrm{MHC}$ in a rat model [49]. These observations are supported by our findings in this study as doxorubicin induced the expression of $\beta$-MHC more than a-MHC (Fig. 13) and also induced the expression of BNP. Interestingly, the expression of $\alpha-\mathrm{MHC}, \beta-\mathrm{MHC}$, and BNP was inhibited by DoxQ, confirming the protective effects of DoxQ on cardiomyocytes.

To elucidate the cardioprotective mechanisms of DoxQ against doxorubicin-induced cardiotoxicity, several in vitro assays were utilized. Given the role of reactive oxygen species in doxorubicin-induced cardiotoxicity and the antioxidant effects of quercetin, the antioxidant capacity of DoxQ was initially examined using a commercial kit in comparison to doxorubicin alone and a mixture of doxorubicin and quercetin. Our results show that the antioxidant capacity of DoxQ was higher than that of doxorubicin in a non-cell environment (Fig. 7). Based on this observation, DCF assay was undertaken to measure the levels of reactive oxygen species in RL-14 cells. The levels of reactive oxygen species generated by DoxQ were lower than those by doxorubicin alone (Fig. 13), suggesting that the presence of quercetin likely scavenges the reactive oxygen species generated by doxorubicin and limits its toxic effects on cardiomyocytes. This observation is also supported by the effects of DoxQ on the expression of oxidative stress markers GST-A1 and HO-1. The inhibitory effects of DoxQ on the expression of GST-A1 (Fig. 14a), which is overexpressed when cells are under oxidative stress, imply the lower ROS generated by DoxQ than doxorubicin alone.

Additionally, the inhibitory effects on mRNA expression of HO-1 by doxorubicin and not DoxQ further support the cardioprotective effects of DoxQ as elevated HO-1 levels have protective effects on cardiomyocytes [50]. To further investigate the mechanisms involved in cardioprotection by DoxQ, the effects of DoxQ on the gene expression and catalytic activity of CYP1B1 were explored in RL-14 cells. CYP1B1 is a member of CYP450 metabolic enzymes and catalyzes the formation of mid-chain HETE metabolites of arachidonic acid, which are cardiotoxic [51]. CYP1B1 also has a role in modulating cellular oxidative stress [52]. A recent study showed that doxorubicin-induced cytotoxicity is mediated by the CYP1B1 pathway [53]. Our results demonstrate that doxorubicin induced the expression of CYP1B1 and its catalytic activity in RL-14 cell, while DoxQ reversed these effects (Fig. 15), suggesting that DoxQ attenuates doxorubicin-induced cardiotoxicity at least partially by CYP1B1 inhibitory activities.

\section{Conclusions}

In conclusion, we developed a novel derivative of doxorubicin with improved in vitro safety while retaining activity. DoxQ was less toxic than doxorubicin in both rat and human cardiomyocytes and retained anticancer activity in triple-negative murine breast cancer cells. The lower level of reactive oxygen species generated by DoxQ compared to doxorubicin as well as the results of the oxidative stress markers examined also suggests cardioprotection in vitro. DoxQ inhibited both the expression of CYP1B1 and also its catalytic activity, proposing an additional mechanism by which DoxQ attenuates cardiotoxicity induced by doxorubicin and improves its tolerability. 
In terms of mitigating the drug delivery barriers of poor oral bioavailability, the initial in vitro results of DoxQ are promising. The cellular uptake of DoxQ by MDCK-MDR cells was higher than that of doxorubicin alone or a doxorubicin plus quercetin mixture. The CYP450 inhibitory activities of DoxQ were higher than those of doxorubicin. DoxQ inhibited CYP3A4 while a mixture of doxorubicin and quercetin demonstrated higher inhibition of P-gp ATPase activity compared to DoxQ and free doxorubicin. If DoxQ is less susceptible to first-pass effect $(F=1-E)$ and the release of quercetin from DoxQ lowers the P-gp efflux effect, then oral absorption of doxorubicin and the possibility that DoxQ is shunted to intestinal lymphatics could potentially increase when $E$ is lowered. To the best of our knowledge, this is the first study that utilizes quercetin as a lymphatically targeted carrier for doxorubicin to improve its bioavailability and safety and mechanistically elucidate the efficacy and safety of the novel conjugate DoxQ. Future in vivo experiments in light of the in vitro observations using this novel drug delivery approach are warranted and are in progress by our laboratory.

\section{Acknowledgments}

The authors would like to acknowledge the College of Pharmacy, Faculty of Health Sciences, Kuwait University, for the graduate scholarship awarded to S.A.

Z.H.M. is a recipient of the Izaak Walton Killam Memorial Scholarship and Alberta Innovates Health Solution Graduate Student Scholarship.

\section{References}

1. Thorn CF, Oshiro C, Marsh S, Hernandez-Boussard T, McLeod H, Klein TE, Altman RB. Doxorubicin pathways: pharmacodynamics and adverse effects. Pharmacogenet Genomics. 2011; 21(7):440-6. [PubMed: 21048526]

2. Swift LP, Rephaeli A, Nudelman A, Phillips DR, Cutts SM. Doxorubicin-DNA adducts induce a non-topoisomerase II-mediated form of cell death. Cancer Res. 2006; 66(9):4863-71. [PubMed: 16651442]

3. Agudelo D, Bourassa P, Bérubé G, Tajmir-Riahi HA. Intercalation of antitumor drug doxorubicin and its analogue by DNA duplex: structural features and biological implications. Int J Biol Macromol. 2014; 66:144-50. [PubMed: 24560949]

4. Carvalho FS, Burgeiro A, Garcia R, Moreno AJ, Carvalho RA, Oliveira PJ. Doxorubicin-induced cardiotoxicity: from bioenergetic failure and cell death to cardiomyopathy. Med Res Rev. 2014; 34(1):106-35. [PubMed: 23494977]

5. Gustafson DL, Merz AL, Long ME. Pharmacokinetics of combined doxorubicin and paclitaxel in mice. Cancer Lett. 2005; 220:161-9. [PubMed: 15766591]

6. Lee HJ, Lee MG. Effects of dexamethasone on the pharmacokinetics of adriamycin after intravenous administration to rats. Res Commun Mol Pathol Pharmacol. 1999; 105:87-96. [PubMed: 10850372]

7. Matsumura Y, Hamaguchi T, Ura T, Muro K, Yamada Y, Shimada Y, Shirao K, Okusaka T, Ueno H, Ikeda M, Watanabe N. Phase I clinical trial and pharmacokinetic evaluation of NK911, a micelleencapsulated doxorubicin. Br J Cancer. 2004; 91(10):1775-81. [PubMed: 15477860]

8. Ríhová B, Strohalm J, Prausová J, Kubácková K, Jelínková M, Rozprimová L, Sírová M, Plocová D, Etrych T, Subr V, Mrkvan T, Kovár M, Ulbrich K. Cytostatic and immunomobilizing activities of polymer-bound drugs: experimental and first clinical data. J Control Release. 2003; 91(1-2):1-16. [PubMed: 12932633]

9. Tolcher AW, Sugarman S, Gelmon KA, Cohen R, Saleh M, Isaacs C, Young L, Healey D, Onetto N, Slichenmyer W. Randomized phase II study of BR96-doxorubicin conjugate in patients with metastatic breast cancer. J Clin Oncol. 1999; 17(2):478-84. [PubMed: 10080588] 
10. Soloman R, Gabizon AA. Clinical pharmacology of liposomal anthracyclines: focus on pegylated liposomal doxorubicin. Clin Lymphoma Myeloma. 2008; 8(1):21-32. [PubMed: 18501085]

11. Davies, NM., Yanez, JA. Flavonoid pharmacokinetics: methods of analysis, preclinical and clinical pharmacokinetics, safety, and toxicology. 1. John Wiley and Sons; 2013.

12. Liu L, Gao C, Yao P, Gong Z. Quercetin alleviates high-fat diet-induced oxidized low-density lipoprotein accumulation in the liver: implication for autophagy regulation. Biomed Res Int. 2015; 2015:607531. [PubMed: 26697490]

13. He Y, Cao X, Liu X, Li X, Xu Y, Liu J, Shi J. Quercetin reverses experimental pulmonary arterial hypertension by modulating the TrkA pathway. Exp Cell Res. 2015; 339(1):122-34. [PubMed: 26476374]

14. Gormaz JG, Quintremil S, Rodrigo R. Cardiovascular disease: a target for the pharmacological effects of quercetin. Curr Top Med Chem. 2015; 15(17):1735-42. [PubMed: 25915608]

15. Chirumbolo $S$. The role of quercetin, flavonols and flavones in modulating inflammatory cell function. Inflamm Allergy Drug Targets. 2010; 9(4):263-85. [PubMed: 20887269]

16. Wang G, Wang J, Luo J, Wang L, Chen X, Zhang L, Jiang S. PEG2000-DPSE-coated quercetin nanoparticles remarkably enhanced anticancer effects through induced programed cell death on C6 glioma cells. J Biomed Mater Res A. 2013; 101(11):3076-85. [PubMed: 23529952]

17. Jiang P, Burczynski F, Campbell C, Pierce G, Austria JA, Briggs CJ. Rutin and flavonoid contents in three buckwheat species Fagopyrum esculentum, F. tataricum, and F. homotropicum and their protective effects against lipid peroxidation. Food Res Int. 2007; 40:356-64.

18. Kang JT, Moon JH, Choi JY, Park SJ, Kim SJ, Saadeldin IM, Lee BC. Effect of antioxidant flavonoids (quercetin and taxifolin) on in vitro maturation of porcine oocytes. Asian-Australas $\mathbf{J}$ Anim Sci. 2016; 29(3):352-8. [PubMed: 26950865]

19. Atashpour S, Fouladdel S, Movahhed TK, Barzegar E, Ghahremani MH, Ostad SN, Azizi E. Quercetin induces cell cycle arrest and apoptosis in CD133(+) cancer stem cells of human colorectal HT29 cancer cell line and enhances anticancer effects of doxorubicin. Iran J Basic Med Sci. 2015; 18(7):635-43. [PubMed: 26351552]

20. Minaei A, Sabzichi M, Ramezani F, Hamishehkar H, Samadi N. Co-delivery with nano-quercetin enhances doxorubicin-mediated cytotoxicity against MCF-7 cells. Mol Biol Rep. 2016; 43(2):99105. [PubMed: 26748999]

21. Wang G, Zhang J, Liu L, Sharma S, Dong Q. Quercetin potentiates doxorubicin mediated antitumor effects against liver cancer through p53/Bcl-xl. PLoS One. 2012; 7(12):e51764. [PubMed: 23240061]

22. Chen FY, Cao LF, Wan HX, Zhang MY, Cai JY, Shen LJ, Zhong JH, Zhong H. Quercetin enhances adriamycin cytotoxicity through induction of apoptosis and regulation of mitogen-activated protein kinase/extracellular signal-regulated kinase/c-Jun N-terminal kinase signaling in multidrugresistant leukemia K562 cells. Mol Med Rep. 2015; 11(1):341-8. [PubMed: 25339540]

23. Chen JY, Hu RY, Chou HC. Quercetin-induced cardioprotection against doxorubicin cytotoxicity. J Biomed Sci. 2013; 20:95. [PubMed: 24359494]

24. Kaiserová H, Simůnek T, Van der Vijgh WJ, Bast A, Kvasnicková E. Flavonoids as protectors against doxorubicin cardiotoxicity: role of iron chelation, antioxidant activity and inhibition of carbonyl reductase. Biochim Biophys Acta. 2007; 1772(9):1065-74. [PubMed: 17572073]

25. Choi JS, Piao YJ, Kang KW. Effects of quercetin on the bioavailability of doxorubicin in rats: role of CYP3A4 and P-gp inhibition by quercetin. Arch Pharm Res. 2011; 34(4):607-13. [PubMed: 21544726]

26. Chen IL, Tsai YJ, Huang CM, Tsai TH. Lymphatic absorption of quercetin and rutin in rat and their pharmacokinetics in systemic plasma. J Agric Food Chem. 2010; 58(1):546-51. [PubMed: 19916501]

27. Kim MK, Park KS, Yeo WS, Choo H, Chong Y. In vitro solubility, stability and permeability of novel quercetin-amino acid conjugates. Bioorg Med Chem. 2009; 17:1164-71. [PubMed: 19128975]

28. Liu Y, Schubert D. Cytotoxic amyloid peptides inhibit cellular 3-(4, 5-dimethylthiazol-2-yl)-2,5diphenyltetrazolium bromide (MTT) reduction by enhancing MTT formazan exocytosis. J Neurochem. 1997; 69(6):2285-93. [PubMed: 9375659] 
29. Maayah ZH, El Gendy MA, El-Kadi AO, Korashy HM. Sunitinib, a tyrosine kinase inhibitor, induces cytochrome P450 1A1 gene in human breast cancer MCF7 cells through ligandindependent aryl hydrocarbon receptor activation. Arch Toxicol. 2013; 87(5):847-56. [PubMed: 23288144]

30. Zordoky BN, Aboutabl ME, El-Kadi AO. Modulation of cytochrome P450 gene expression and arachidonic acid metabolism during isoproterenol-induced cardiac hypertrophy in rats. Drug Metab Dispos. 2008; 36(11):2277-86. [PubMed: 18725507]

31. Maayah ZH, Ansari MA, El Gendy MA, Al-Arifi MN, Korashy HM. Development of cardiac hypertrophy by sunitinib in vivo and in vitro rat cardiomyocytes is influenced by the aryl hydrocarbon receptor signaling pathway. Arch Toxicol. 2014; 88(3):725-38. [PubMed: 24247421]

32. Livak KJ, Schmittgen TD. Analysis of relative gene expression data using real-time quantitative PCR and the 2(-Delta Delta C(T)) method. Methods. 2001; 25(4):402-8. [PubMed: 11846609]

33. Kennedy SW, Lorenzen A, James CA, Collins BT. Ethoxyresorufin-O-deethylase and porphyrin analysis in chicken embryo hepatocyte cultures with a fluorescence multiwell plate reader. Anal Biochem. 1993; 211(1):102-12. [PubMed: 8323021]

34. Lo SN, Chang YP, Tsai KC, Chang CY, Wu TS, Ueng YF. Inhibition of CYP1 by berberine, palmatine, and jatrorrhizine: selectivity, kinetic characterization, and molecular modeling. Toxicol Appl Pharmacol. 2013; 272(3):671-80. [PubMed: 23886934]

35. Pham A, Bortolazzo A, White JB. Rapid dimerization of quercetin through an oxidative mechanism in the presence of serum albumin decreases its ability to induce cytotoxicity in MDAMB-231 cells. Biochem Biophys Res Commun. 2012; 427(2):415-20. [PubMed: 23000408]

36. Lorusso D, Stefano AD, Carone V, Fagotti A, Pisconti S, Scambia G. Pegylated liposomal doxorubicin-related palmar-plantar erythrodysesthesia ('hand-foot' syndrome). Ann Oncol. 2007; 18(7):1159-64. [PubMed: 17229768]

37. Cai S, Thati S, Bagby TR, Diab HM, Davies NM, Cohen MS, Forrest ML. Localized doxorubicin chemotherapy with a biopolymeric nanocarrier improves survival and reduces toxicity in xenografts of human breast cancer. J Control Release. 2010; 146(2):212-8. [PubMed: 20403395]

38. Murota K, Terao J. Quercetin appears in the lymph of unanesthetized rats as its phase II metabolites after administered into the stomach. FEBS Lett. 2005; 579(24):5343-6. [PubMed: 16194534]

39. Murota K, Cermak R, Terao J, Wolffram S. Influence of fatty acid patterns on the intestinal absorption pathway of quercetin in thoracic lymph duct-cannulated rats. Br J Nutr. 2013; 109(12): 2147-53. [PubMed: 23200408]

40. Chan LM, Lowes S, Hirst BH. The ABCs of drug transport in intestine and liver: efflux proteins limiting drug absorption and bioavailability. Eur J Pharm Sci. 2004; 21(1):25-51. [PubMed: 14706810]

41. Qian F, Wei D, Liu J, Yang S. Molecular model and ATPase activity of carboxyl-terminal nucleotide binding domain from human P-glycoprotein. Biochem Mosc. 2016; 71(Suppl 1):S1824. 11-12 (2006).

42. Kim JE, Cho HJ, Kim JS, Shim CK, Chung SJ, Oak MH, Yoon IS, Kim DD. The limited intestinal absorption via paracellular pathway is responsible for the low oral bioavailability of doxorubicin. Xenobiotica; the fate of foreign compounds in biological systems. 2013; 43:579-91. [PubMed: 23252722]

43. Maayah ZH, Elshenawy OH, Althurwi HN, Abdelhamid G, El-Kadi AO. Human fetal ventricular cardiomyocyte, RL-14 cell line, is a promising model to study drug metabolizing enzymes and their associated arachidonic acid metabolites. J Pharmacol Toxicol Methods. 2015; 71:33-41. [PubMed: 25454080]

44. Kobashigawa LC, Xu YC, Padbury JF, Tseng YT, Yano N. Metformin protects cardiomyocyte from doxorubicin induced cytotoxicity through an AMP-activated protein kinase dependent signaling pathway: an in vitro study. PLoS One. 2014; 9(8):e104888. [PubMed: 25127116]

45. Mross K, Maessen P, van der Vijgh WJ, Gall H, Boven E, Pinedo HM. Pharmacokinetics and metabolism of epidoxorubicin and doxorubicin in humans. J Clin Oncol. 1988; 6(3):517-26. [PubMed: 3162516] 
46. Robert J, Vrignaud P, Nguyen-Ngoc T, Iliadis A, Mauriac L, Hurteloup P. Comparative pharmacokinetics and metabolism of doxorubicin and epirubicin in patients with metastatic breast cancer. Cancer Treat Rep. 1985; 69(6):633-40. [PubMed: 3893693]

47. McHowat J, Swift LM, Arutunyan A, Sarvazyan N. Clinical concentrations of doxorubicin inhibit activity of myocardial membrane-associated, calcium-independent phospholipase A(2). Cancer Res. 2001; 61(10):4024-9. [PubMed: 11358821]

48. Doroshow JH, Akman S, Chu FF, Esworthy S. Role of the glutathione-glutathione peroxidase cycle in the cytotoxicity of the anticancer quinones. Pharmacol Ther. 1990; 47(3):359-70. [PubMed: 2290853]

49. Chen YL, Chung SY, Chai HT, Chen CH, Liu CF, Chen YL, Huang TH, Zhen YY, Sung PH, Sun CK, Chua S, Lu HI, Lee FY, Sheu JJ, Yip HK. Early administration of carvedilol protected against doxorubicin-induced cardiomyopathy. J Pharmacol Exp Ther. 2015; 355(3):516-27. [PubMed: 26511374]

50. Issan Y, Kornowski R, Aravot D, Shainberg A, Laniado-Schwartzman M, Sodhi K, Abraham NG, Hochhauser E. Heme oxygenase-1 induction improves cardiac function following myocardial ischemia by reducing oxidative stress. PLoS One. 2014; 9(3):e92246. [PubMed: 24658657]

51. Maayah ZH, El-Kadi AO. The role of mid-chain hydroxyeicosatetraenoic acids in the pathogenesis of hypertension and cardiac hypertrophy. Arch Toxicol. 2016 Jan; 90(1):119-36. [PubMed: 26525395]

52. Tang Y, Scheef EA, Wang S, Sorenson CM, Marcus CB, Jefcoate CR, Sheibani N. CYP1B1 expression promotes the proangiogenic phenotype of endothelium through decreased intracellular oxidative stress and thrombospondin-2 expression. Blood. 2009; 113(3):744-54. [PubMed: 19005183]

53. Maayah ZH, Althurwi HN, Abdelhamid G, Lesyk G, Jurasz P, El-Kadi AO. CYP1B1 inhibition attenuates doxorubicin-induced cardiotoxicity through a mid-chain HETEs-dependent mechanism. Pharmacol Res. 2016; 105:28-43. [PubMed: 26772815] 
<smiles>CC(C)(C)OC(=O)CN</smiles><smiles>CC(C)(C)OC(=O)CNC(=O)Oc1ccc(-c2oc3cc(O)cc(O)c3c(=O)c2O)cc1O</smiles>

Compound 1<smiles>CC(C)C[C@@H](C)C#N</smiles>

HATU/DIPEA/DMF

\section{Compound 2}<smiles>COc1cccc2c1C(=O)c1c(O)c3c(c(O)c1C2=O)CC(O)(C(=O)CO)CC3OC(C)C</smiles><smiles>CC1O[C@@H](C)CC(NC(=O)CNC(=O)Oc2ccc(-c3oc4cc(O)cc(O)c4c(=O)c3O)cc2O)C1O</smiles>

\section{Compound 3}

Fig. 1.

A schematic diagram of DoxQ synthesis 
<smiles>COc1cccc2c1C(=O)c1c(O)c3c(c(O)c1C2=O)CC(O)(C(=O)CO)CC3O[C@H]1CC(NC(=O)CNC(=O)Oc2ccc(-c3oc4cc(O)cc(O)c4c(=O)c3O)cc2O)C(O)C(C)O1</smiles><smiles>COc1cccc2c1C(=O)c1c(O)c3c(c(O)c1C2=O)CC(O)(C(=O)CO)CC3O[C@H]1CC(N)C(O)C(C)O1</smiles><smiles>O=C(O)CNC(=O)c1ccc(-c2oc3cc(O)cc(O)c3c(=O)c2O)cc1O</smiles>
Quercetin-Gly-COOH<smiles>O=c1c(O)c(-c2ccc(O)c(O)c2)oc2cc(O)cc(O)c12</smiles><smiles>NCC(=O)O</smiles>
Quercetin

Glycine

Fig. 2.

A schematic representation of the release of doxorubicin and quercetin from DoxQ 


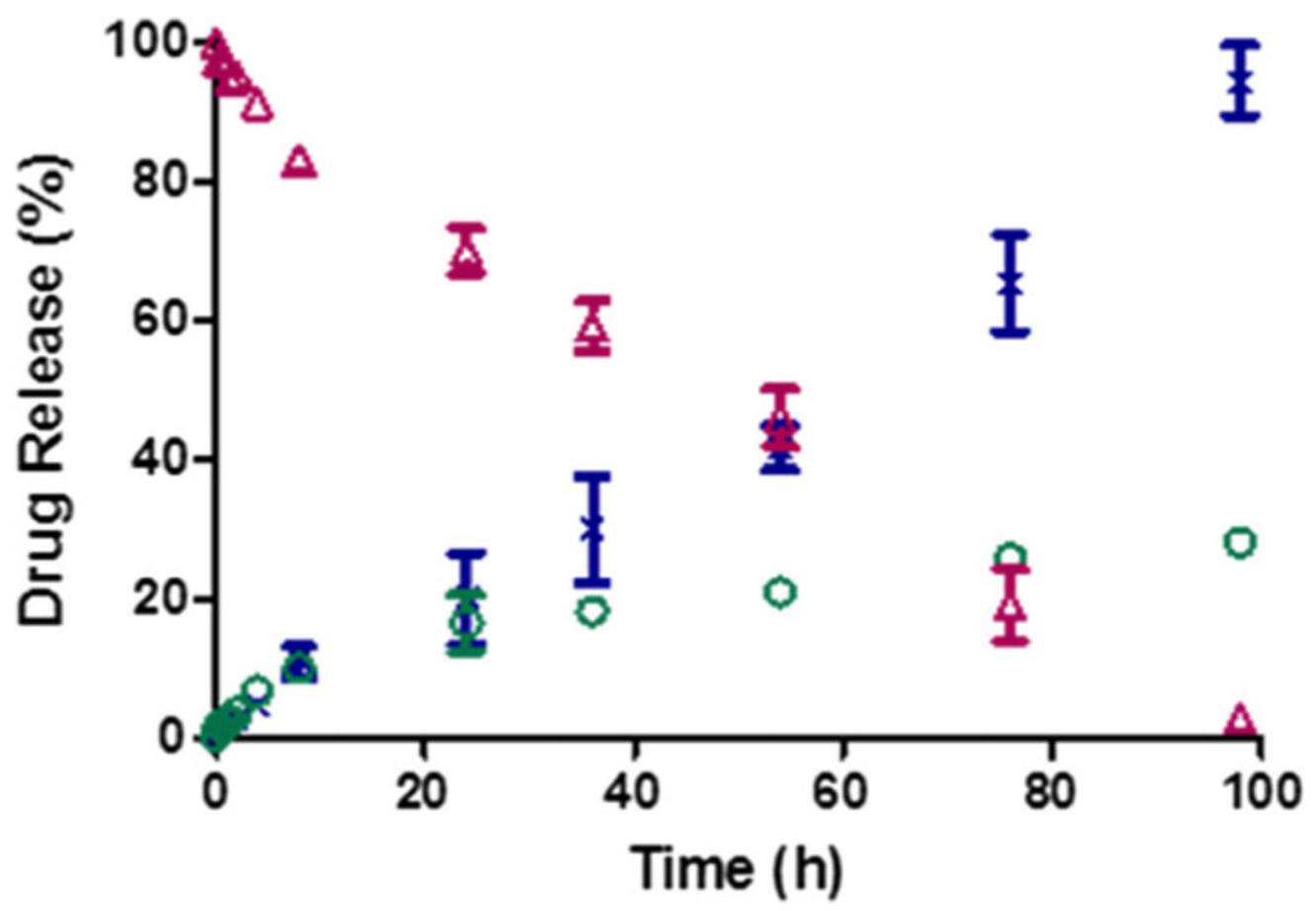

\section{$\triangle \mathrm{DoxQ}$ $\times$ Dox - Quercetin}

Fig. 3.

In vitro release of doxorubicin and quercetin from DoxQ quantified by HPLC. $N=3$; mean \pm SEM 


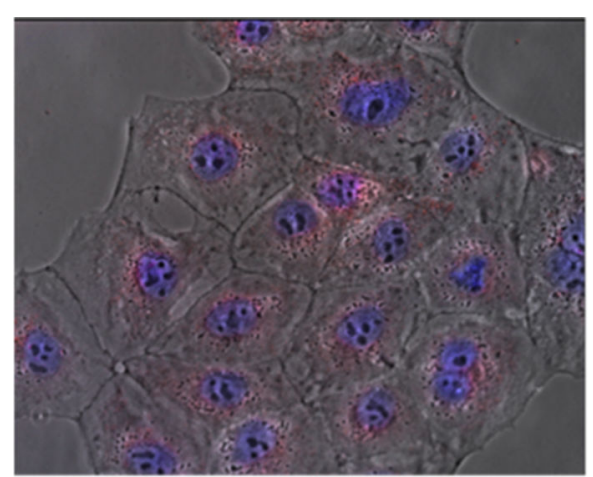

a

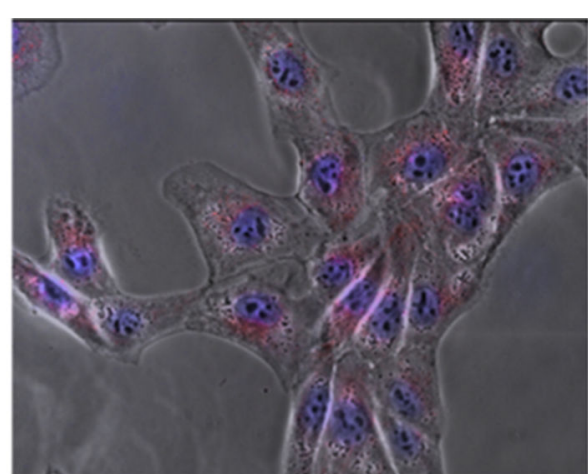

b

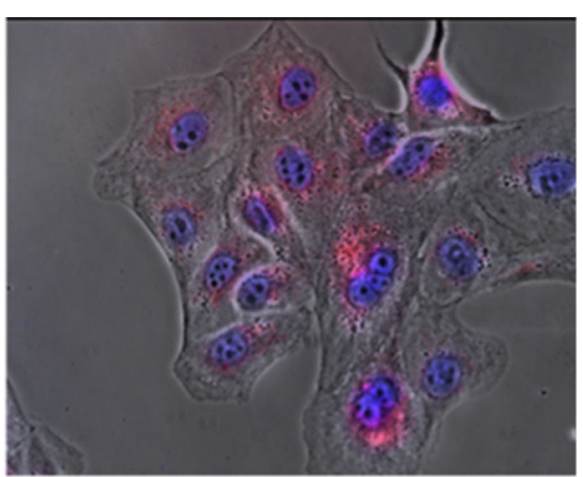

C

Fig. 4.

Fluorescence imaging study of cell uptake of doxorubicin by MDCK-MDR cells (P-gp positive). Cells were treated with a $50 \mathrm{nM}$ free doxorubicin, $\mathbf{b} 50 \mathrm{nM}$ doxorubicin and 50 $\mathrm{nM}$ quercetin, and c $50 \mathrm{nM}$ DoxQ 
a

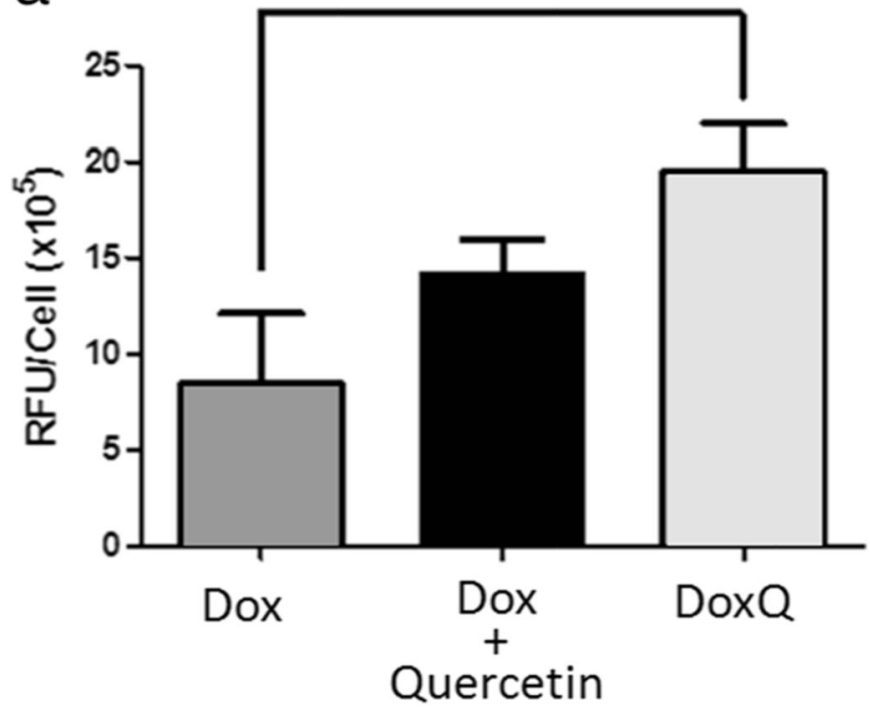

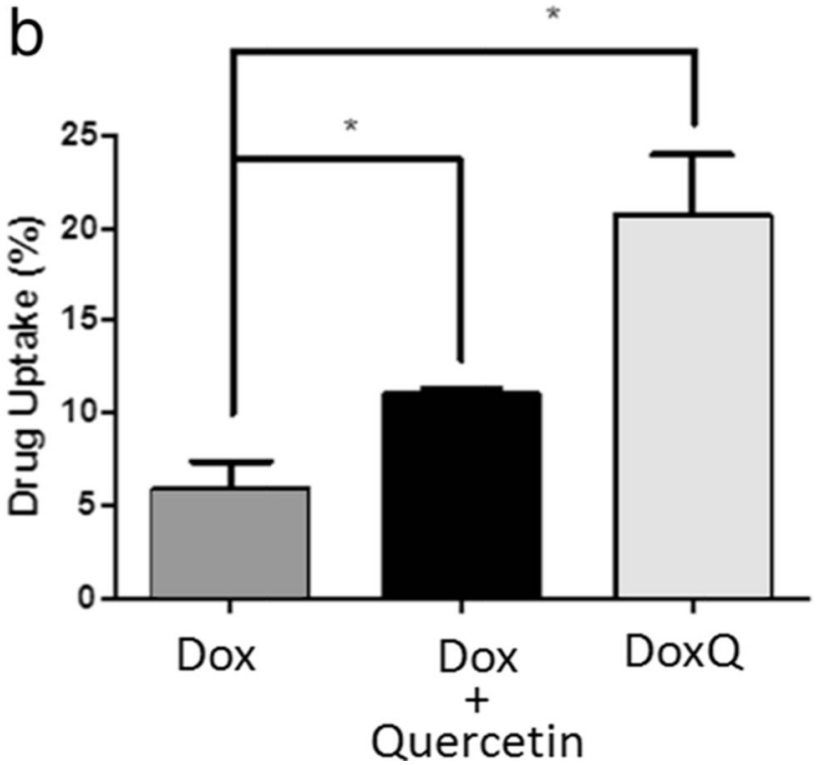

Fig. 5.

a The fluorescence signals analyzed by ImageJ of the images of MDCK-MDR cells after treatment. $N=3$; mean \pm SD. b HPLC quantification of percentage of drug uptake by MDCK-MDR cells (P-gp positive) after treatment. $N=3$; mean $\pm \mathrm{SD}$. $* P<0.05$ 


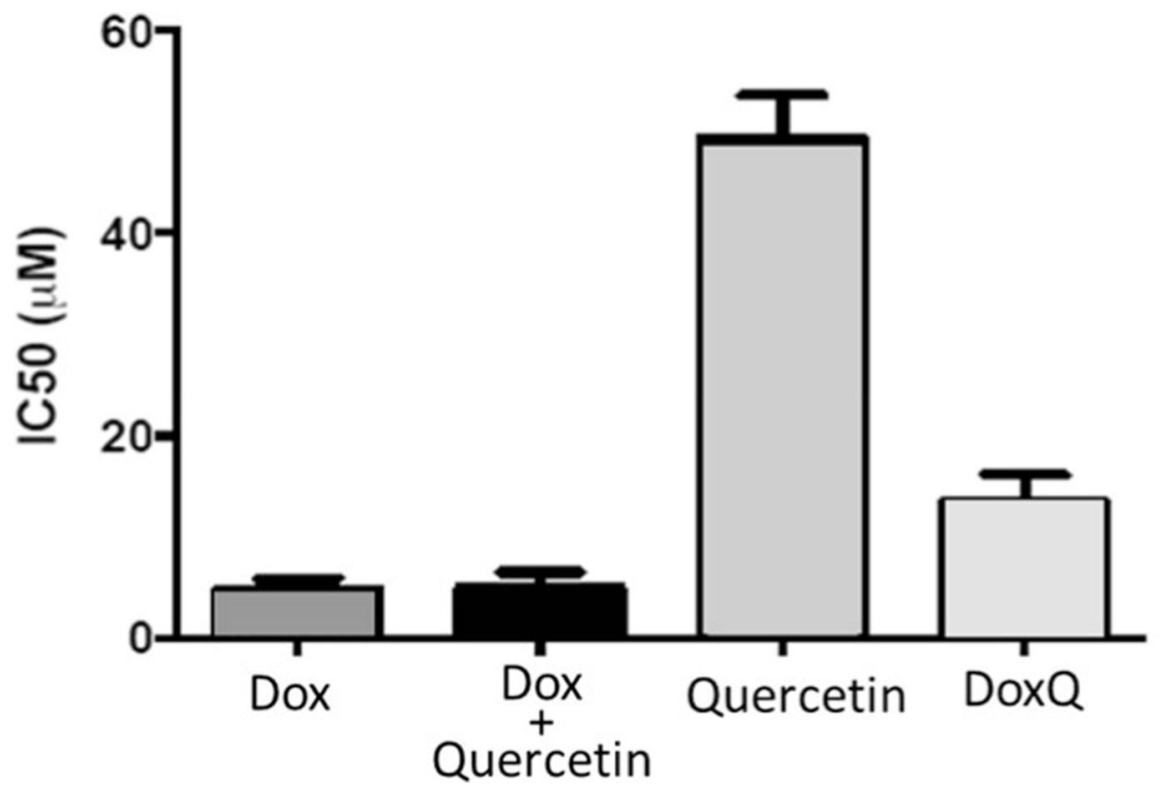

$\square$ Dox

Dox + Quercetin (1:1)

$\square$ Quercetin

$\square$ DoxQ

Fig. 6.

The cytotoxic effects of doxorubicin, a mixture of doxorubicin and quercetin, or DoxQ determined by resazurin blue assay expressed as $\mathrm{IC}_{50}$ after $5 \mu \mathrm{M}$ treatment for $72 \mathrm{~h} . N=4$; mean \pm SD 


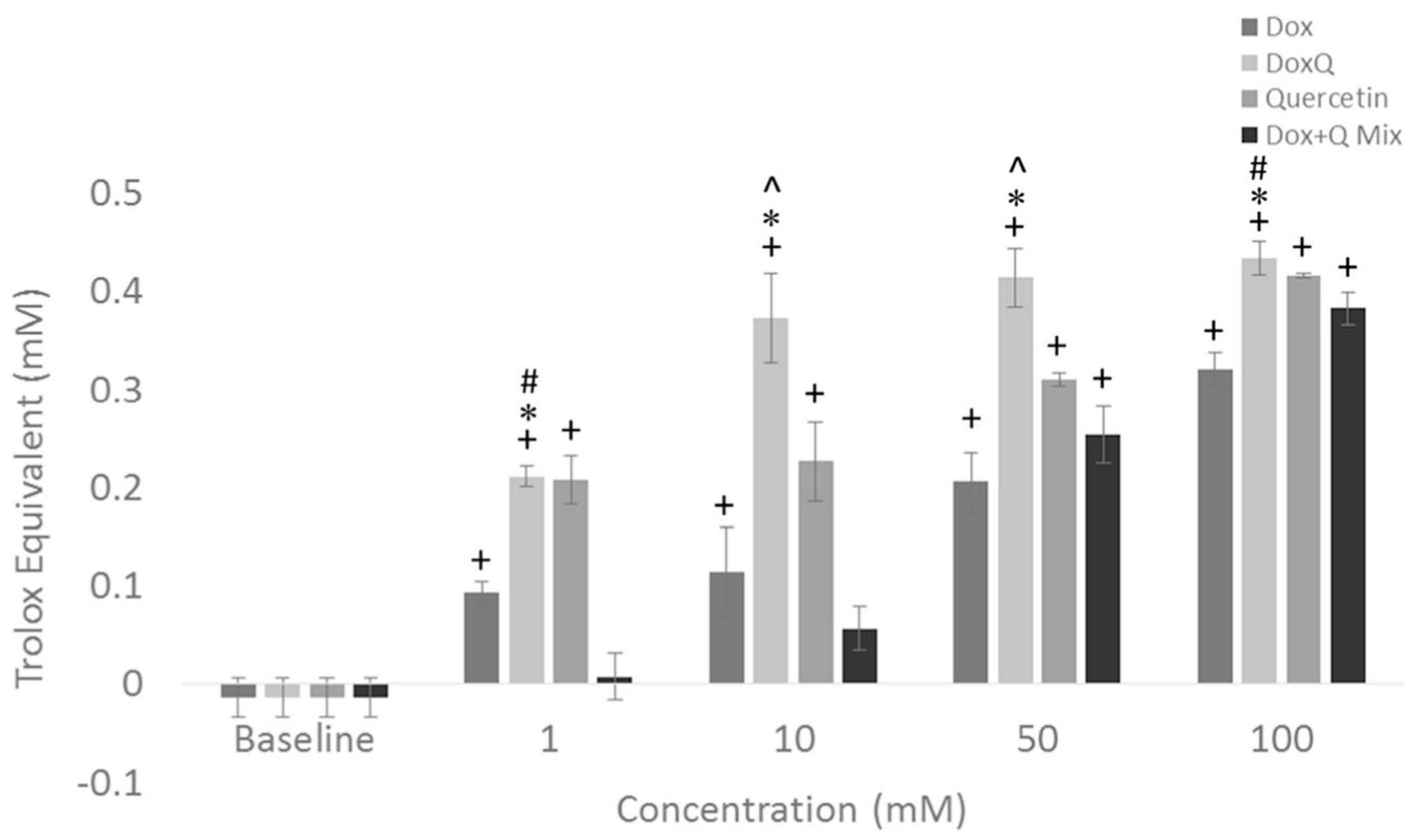

Fig. 7.

Antioxidant activity of DoxQ in comparison to doxorubicin, a mixture of doxorubicin and quercetin, or quercetin alone expressed as Trolox equivalents $(N=4$; mean $\pm \mathrm{SEM}) .+P<$ 0.05 compared to control, $* P<0.05$ compared to doxorubicin, ${ }^{\wedge} P<0.05$ compared to quercetin, $\# P<0.05$ compared to Dox + quercetin mixture 


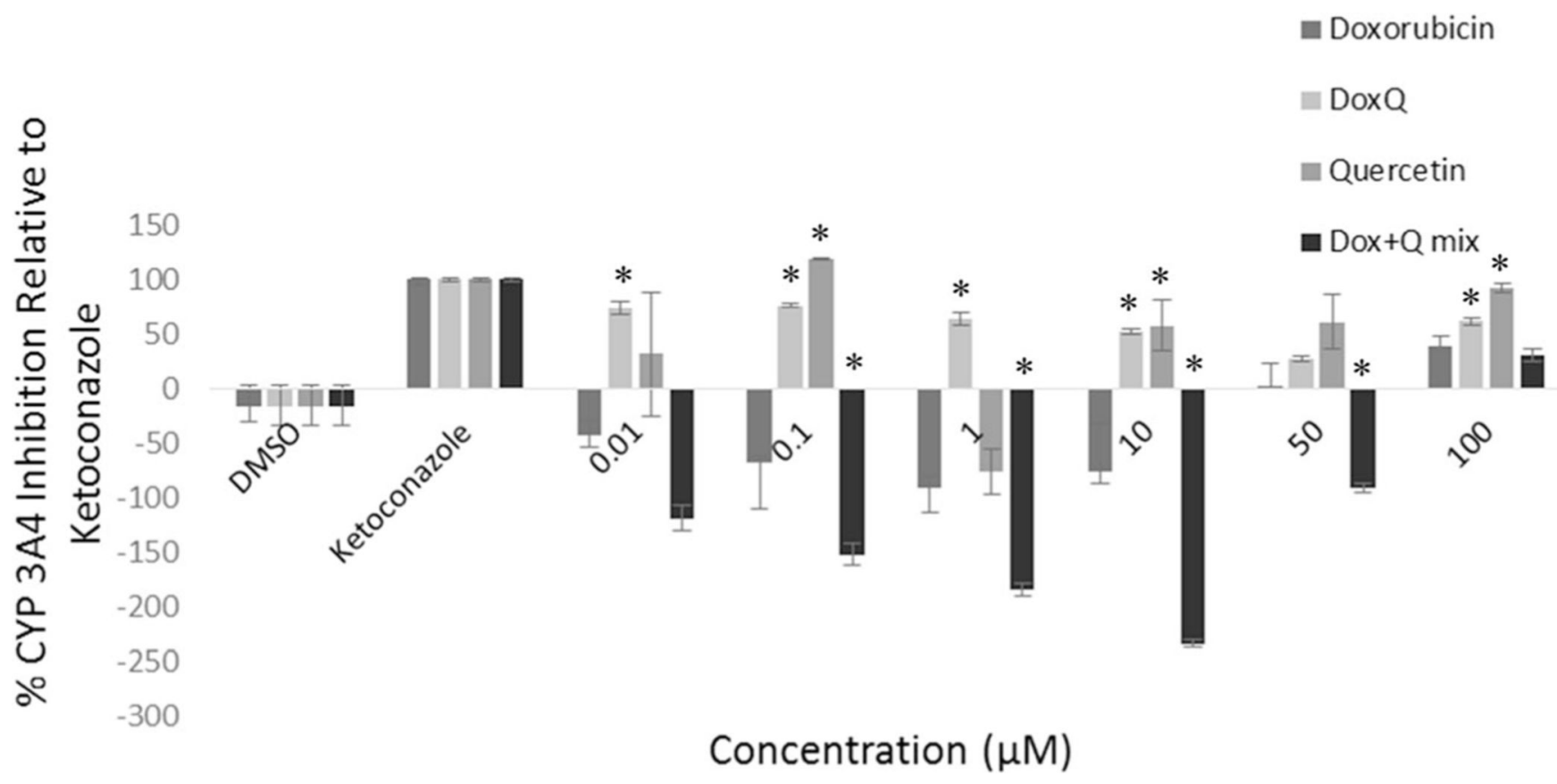

Fig. 8.

CYP3A4 enzyme inhibition expressed as percentage of the positive inhibitor (ketoconazole). $N=4$; mean \pm SEM. $* P<0.05$ compared to doxorubicin 


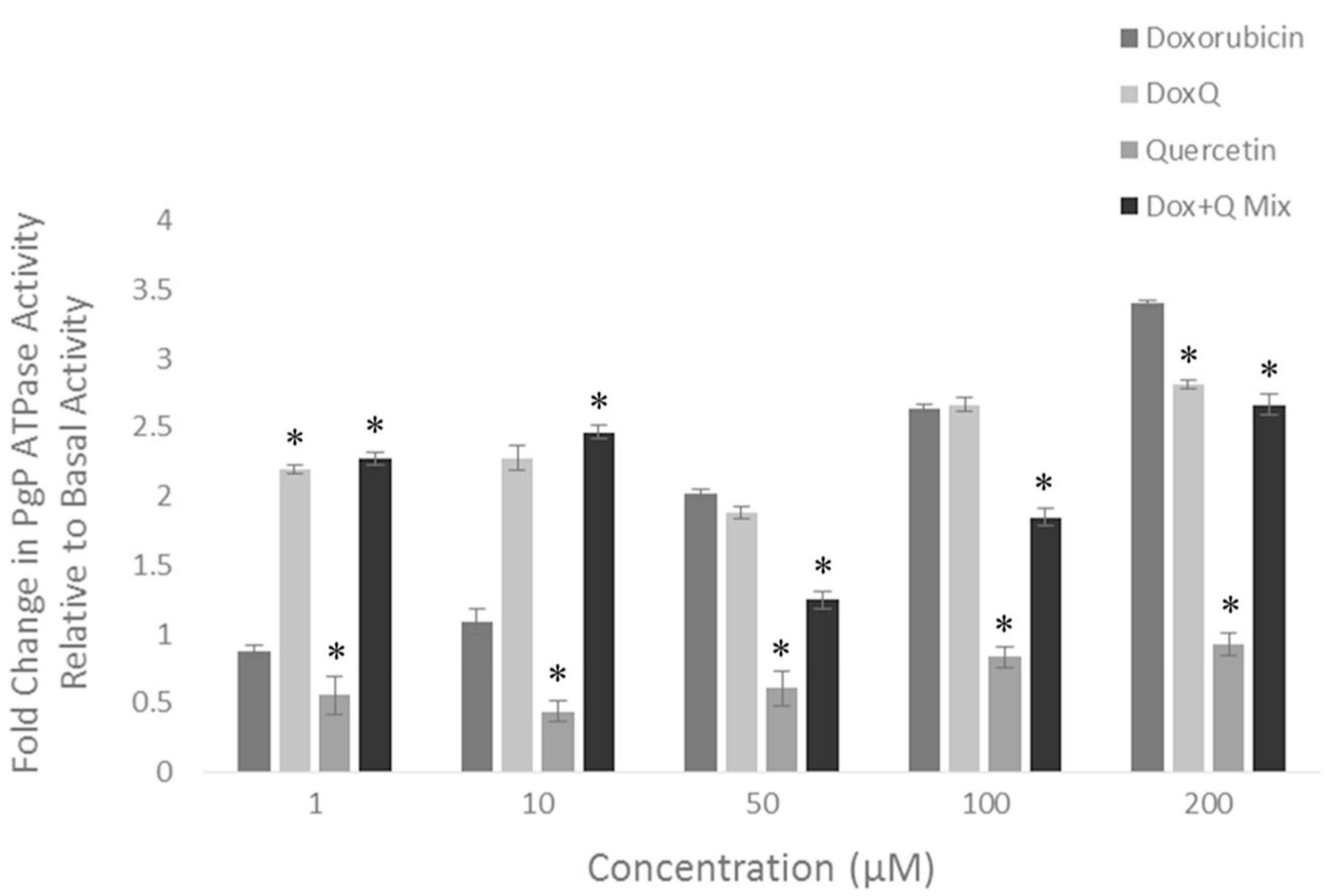

Fig. 9.

Fold change in P-gp ATPase activity of doxorubicin, DoxQ, a mixture of doxorubicin and quercetin, or quercetin at $1,10,50,100$, and $200 \mu \mathrm{M}$ relative to basal activity. $N=4$; mean \pm SEM. $* P<0.05$ compared to doxorubicin 

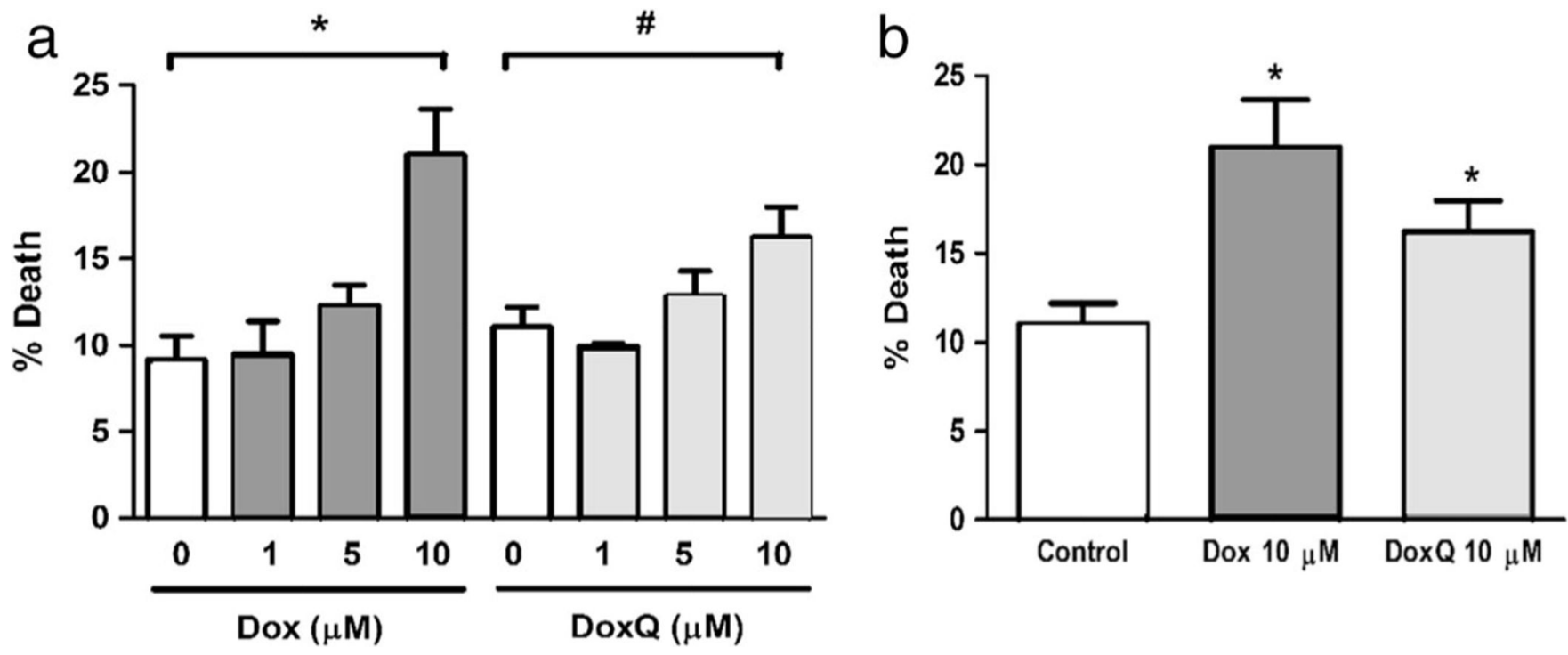

Fig. 10.

Effect of doxorubicin and DoxQ on adult rat cardiomyocyte viability. a Dox versus DoxQ dose response. $N=3$; mean \pm SEM. $* P<0.05$ Dox compared to control; \#P<0.05 DoxQ compared to control. b Dox versus DoxQ $(10 \mu \mathrm{M}) . N=3$; mean \pm SEM. $* P<0.05$ DoxQ compared to doxorubicin 


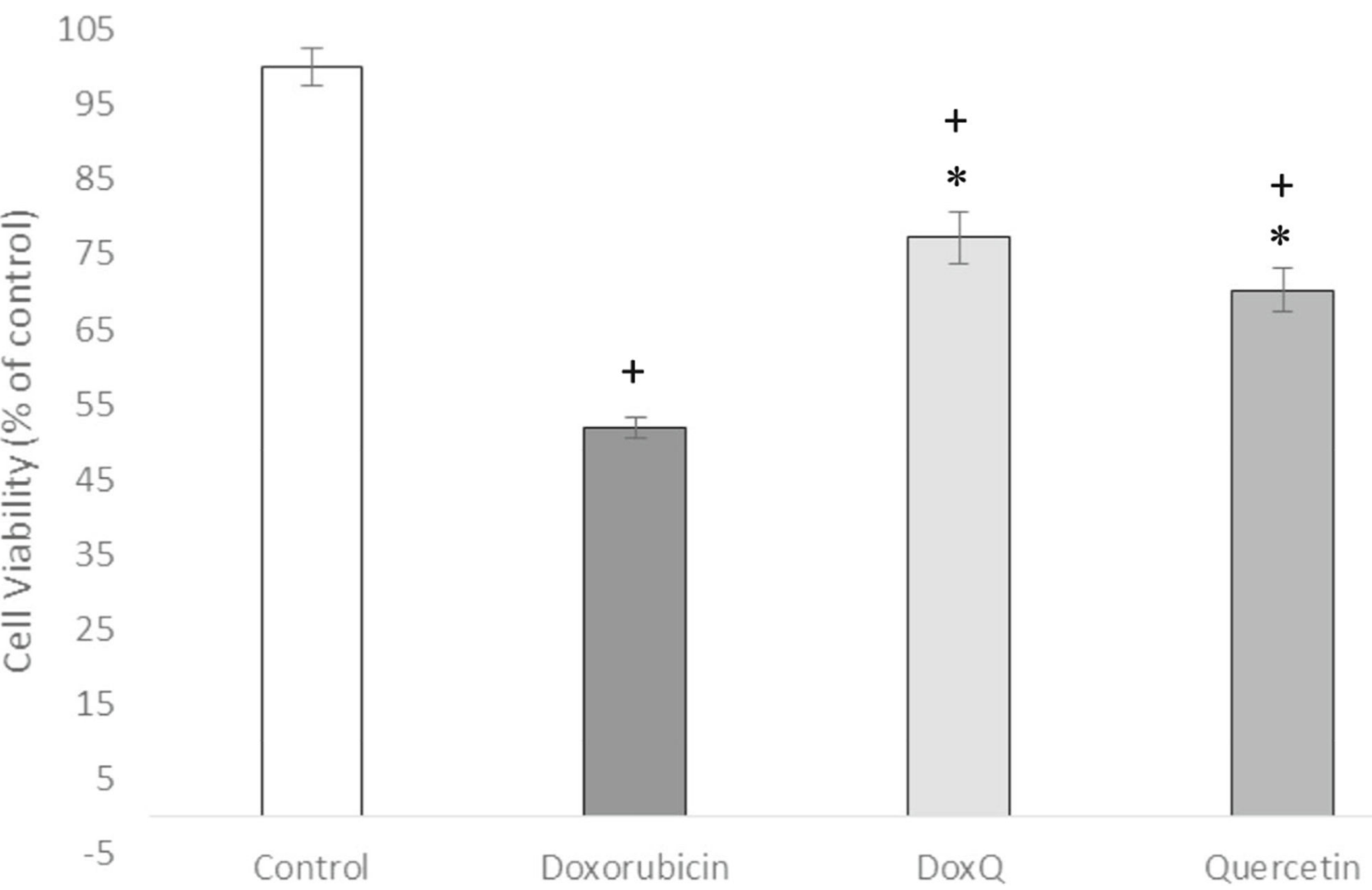

Fig. 11.

Cell viability of human cardiac myocytes (RL-14) measured by MTT assay after drug treatment at $10 \mu \mathrm{M}$ for $24 \mathrm{~h}$. $N=4$; mean \pm SEM. $* P<0.05$ compared to doxorubicin, $+P<$ 0.05 compared to control 


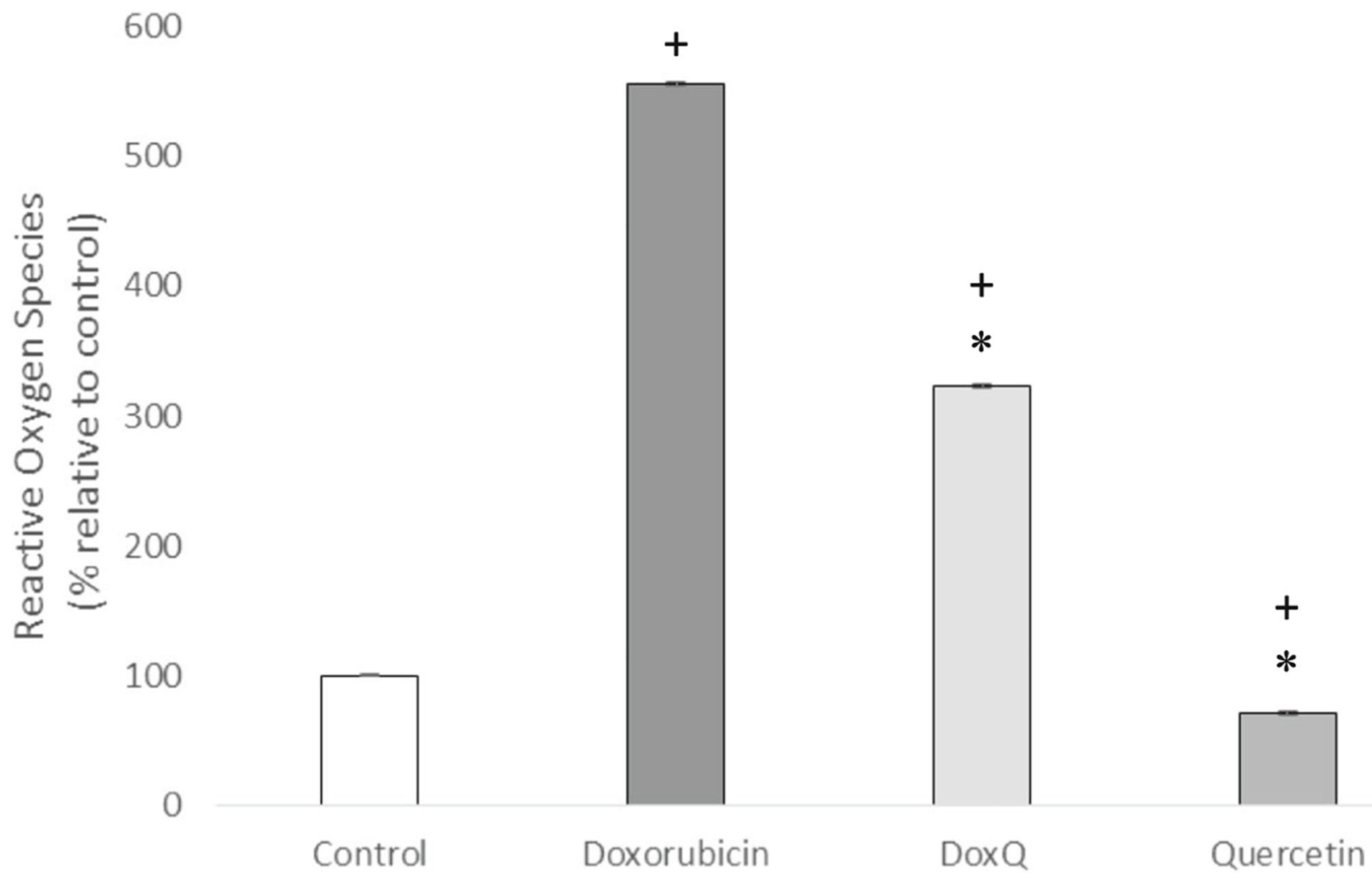

Fig. 12.

Reactive oxygen species levels quantified fluorometrically by dichlorofluorescein (DCF) assay after drug treatment of RL-14 cells at $10 \mu \mathrm{M}$ for $24 \mathrm{~h}$. $N=4$; mean \pm SEM. $* P<0.05$ compared to doxorubicin, $+P<0.05$ compared to control 

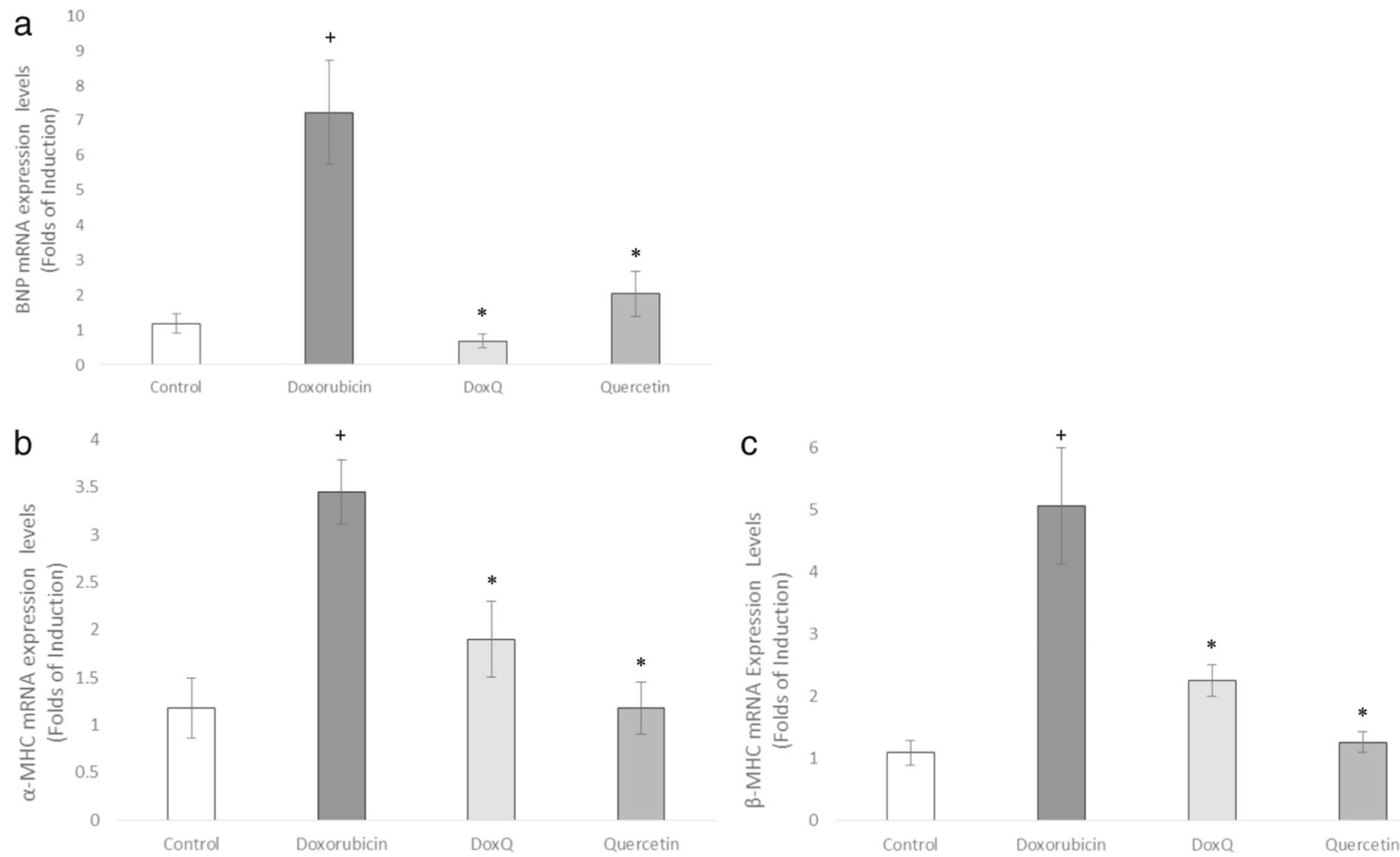

Fig. 13.

Fold expression of cardiac hypertrophy markers in RL-14 cells after treatment at $10 \mu \mathrm{M}$ for $24 \mathrm{~h}$ of doxorubicin, DoxQ, or quercetin. The mRNA expression of a BNP, $\mathbf{b}$ a-MHC, and $\mathbf{c}$ $\beta$-MHC in RL-14 cells. The mRNA expression was quantified by RT-PCR and normalized to $\beta$-actin as a housekeeping gene. $N=6$; mean \pm SEM. $* P<0.05$ compared to doxorubicin, $+P<0.05$ compared to control 
a

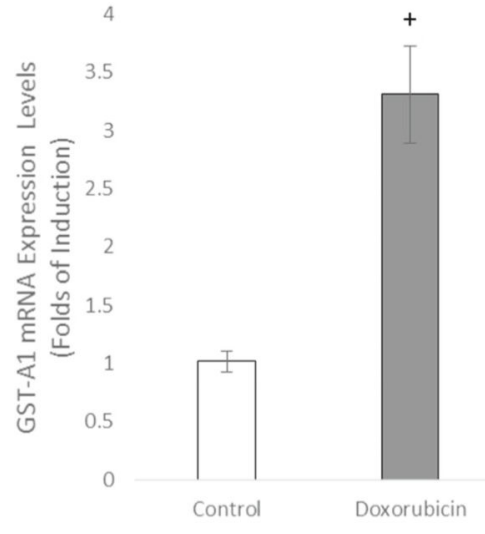

b

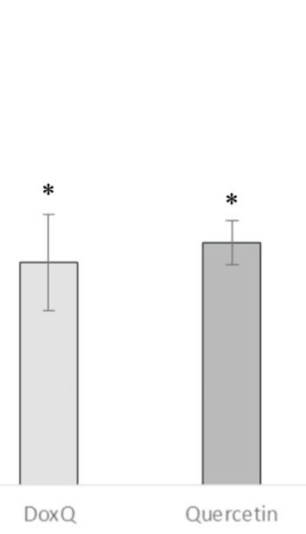

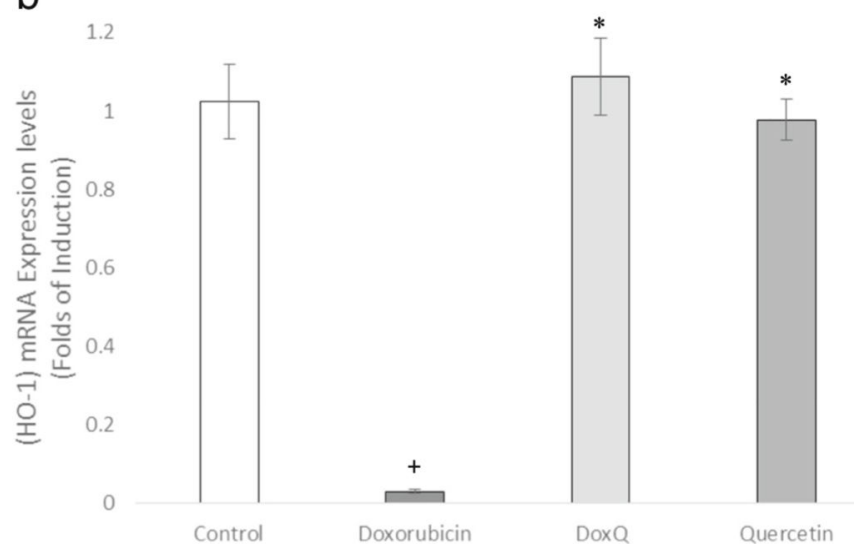

Fig. 14.

Fold expression of oxidative stress markers in RL-14 cells after treatment at $10 \mu \mathrm{M}$ for $24 \mathrm{~h}$ of doxorubicin, DoxQ, or quercetin. The mRNA expression of a GST-A1 and b HO-1 in RL-14 cells. The mRNA expression was quantified by RT-PCR and normalized to $\beta$-actin as a housekeeping gene. $N=6$; mean \pm SEM. $* P<0.05$ compared to doxorubicin, $+P<0.05$ compared to control 
a

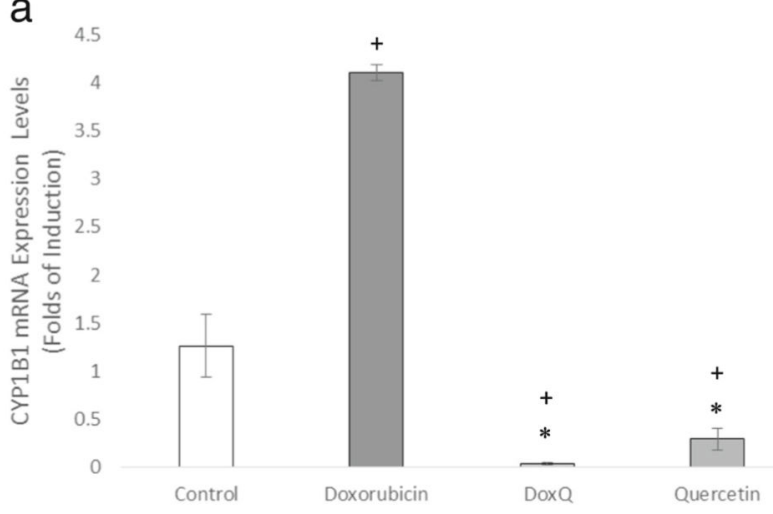

b
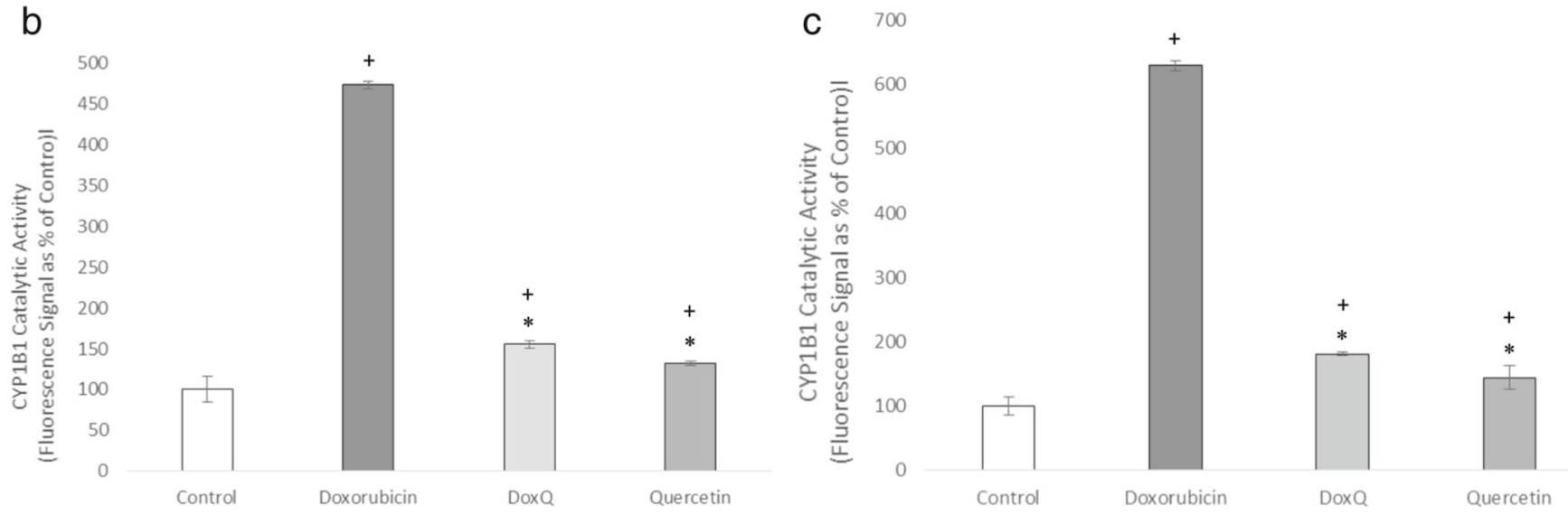

Fig. 15.

a The mRNA expression of CYP1B1 quantified by RT-PCR and normalized to $\beta$-actin as a housekeeping gene. $N=6$; mean \pm SEM. b CYP1B1 catalytic activity determined by MROD assay. $N=3$; mean \pm SEM. c CYP1B1 catalytic activity determined by EROD assay. $N=3$; mean \pm SEM. $* P<0.05$ compared to doxorubicin, $+P<0.05$ compared to control 


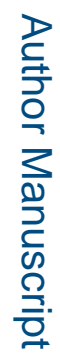
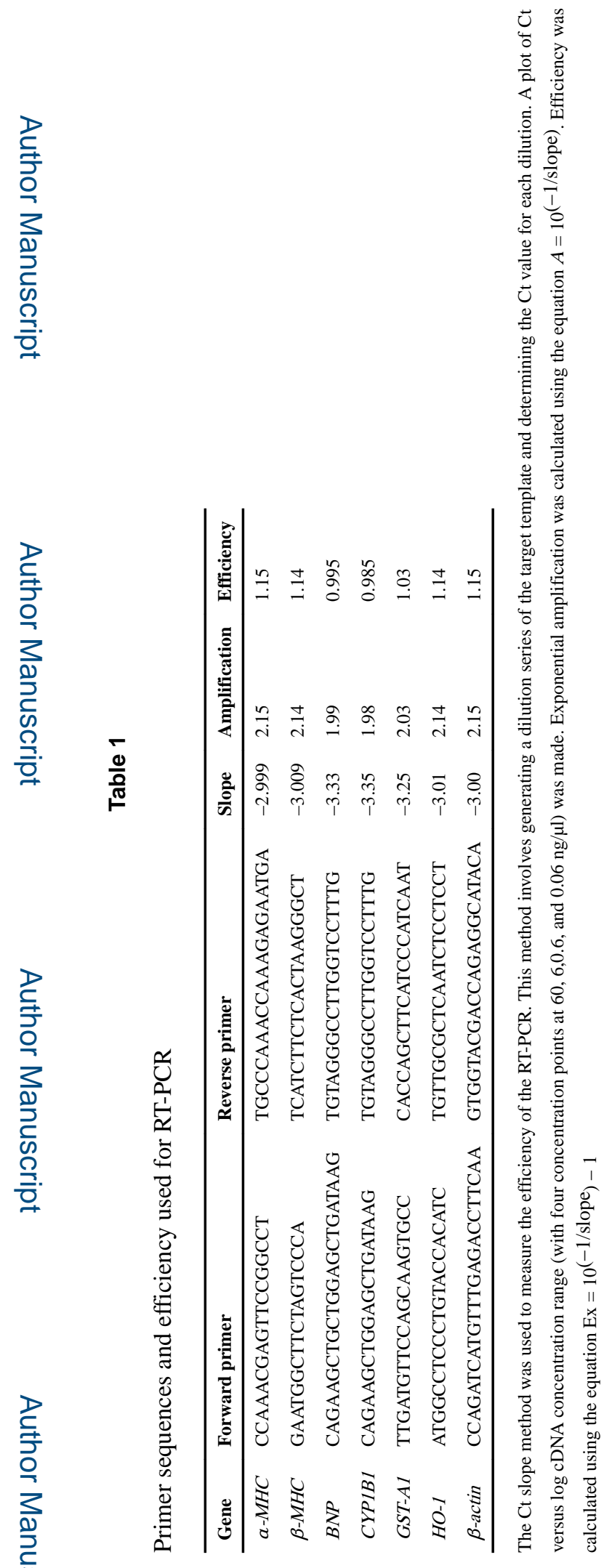

Drug Deliv Transl Res. Author manuscript; available in PMC 2018 August 01. 